\title{
Comprehensive changes of nutritional constituents and antioxidant activities of ginseng sprouts according to the roasting process
}

\author{
Su Cheol Kim ${ }^{1}$, Young Min Kang ${ }^{2}$, Jin A Seong ${ }^{1}$, Hee Yul Lee ${ }^{1}$, \\ Du Yong Cho ${ }^{1}$, Ok Soo Joo ${ }^{1}$, Jin Hwan $\mathrm{Lee}^{3}$, Kye Man Cho ${ }^{1,2 *}$ \\ ${ }^{1}$ Department of Food Science, Gyeongnam National University of Science and Technology, Jinju 52725, Korea \\ ${ }^{2}$ Herbal Medicine Resources Research, Korea Institute of Oriental Medicine, Naju 58245, Korea \\ ${ }^{3}$ Department of Life Resources Industry, Dong-A University, Busan 49315, Korea
}

\section{볶음 처리에 따른 새싹인삼의 영양성분 및 항산화 활성 변화

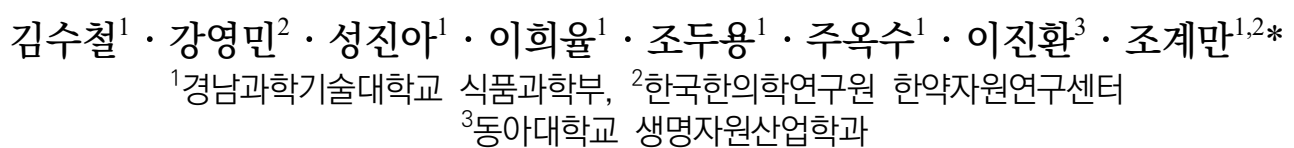

\begin{abstract}
This study comprehensively investigated the physicochemical properties, nutritional constituents, and antioxidant activity of ginseng sprouts (GS) according to the roasting process. The fatty acid and mineral contents of GS were almost unchanged, but the free amino acid contents decreased. Moreover, ginsenoside contents decreased during the roasting process, whereas total phenolics and flavonoids, Maillard reaction products, phenolic acid and flavonol contents increased. In particular, the contents of ginsenoside Re, Rb1, and Rd decreased by $41 \% / 18 \%, 32 \% / 30 \%$, and $\mathbf{1 3 \%} / \mathbf{2 3} \%$ (above/below ground), respectively, during roasting. In contrast, the values of $\mathbf{R g 3}$, compound $\mathrm{K}$, chlorogenic acid, epigallocatechin, and quercetin increased by $167 \% / 229 \%, 287 \% / 196 \%, 190 \% / 231 \%, 370 \% / 229 \%$, and $250 \% / 387 \%$ (above/below ground), respectively. Finally, the antioxidant effects of DPPH and ABTS, the hydroxyl radical scavenging activity and the ferric reducing/antioxidant power of GS increased during the roasting process.
\end{abstract}

Key words : sprout ginseng, roasting process, free amino acid, ginsenoside, antioxidant activity

서 론

새싹채소는 싹채소, 어린 싹이라고도 불리며, 종자로부터 발아하여 모든 부위를 이용하거나 배축부를 절단하여 이용하 는 채소이다. 새싹채소의 경우, 성장을 위해 영양소를 생합성 함으로 성장한 채소에 비해 영양성분이나 생리활성 효과가 우수하다는 보고가 있다. 이에 평상시 미네랄 및 비타민 등을 쉽게 섭취할 수 있는 장점이 있다(Kim과 Lee, 2010). 인삼의 잎을 이용하기 위해서 재배를 하게 되면 밭에서 재배되고 있
는 인삼은 더 성장할 수 없게 되어 뿌리와 잎 모두 사용하기 어렵게 된다. 또한 인삼의 잎은 경화되어 있을 뿐 아니라, 쓴 맛이 너무 강하여 쌈 채소로 이용하기엔 어려움이 크다. 따라 서, 묘삼을 이용하여 새싹인삼을 만들어 인삼의 모든 부위를 다 식용으로 사용할 수 있도록 하여 소비자들에게 제공되고 있다(Seong 등, 2019).

인삼은 현재 뿌리만 사용되는데 이전 연구에 따르면 잎에 도 많은 진세노사이드가 함유되었다는 보고가 있다(Kim 등, 2010). 삼 종류의 주요 성분 중의 하나인 ginsenoside는 ginseng

*Corresponding author. E-mail : kmcho@gntech.ac.kr, Phone : +82-55-751-3272, Fax : +82-55-751-3279

Received 15 December 2020; Revised 10 January 2021; Accepted 18 January 2021.

Copyright (c) The Korean Society of Food Preservation.

This is an Open Access article distributed under the terms of the Creative Commons Attribution Non-Commercial License (http://creativecommons.org/licenses/by-nc/4.0) which permits unrestricted non-commercial use, distribution, and reproduction in any medium, provided the original work is properly cited. 
과 glucoside의 합성어로 triterpenoid의 dammarane계의 인삼 속의 식물에만 존재하는 특유 사포닌이다. C-3, C-6 또는 C-20번 위치에 glucose, xylose와 rhamnose 등의 당을 결합 하는 일반적인 소수성 스테로이드 형태의 구조를 가지며, 이 들은 protopanaxadiol(PD), protopanaxatriol(PT), oleanolic acid 및 octillol 계로 나눠진다(Park 등, 2017). PD계 ginsenoside는 Rb1와 Rb2, Rb3, Rc, Rd 등이 있고, PT계는 Re 와 Rf, Rg1 등이 있다(Park 등, 2005). 한편, 잎에는 지하부에 함유되어 있지 않은 ginsenoside F1과 F3 등과 같은 성분 등 이 존재한다(Lee 등, 2004).

인삼과 같은 식물체는 특유의 쓴맛이 있어 생으로 섭취하 기에 어려움이 있다. 식품의 가공 공정 중 하나로 볶음 공정 은 쓴맛을 지닌 식품의 갈변반응을 촉진하며, 향기성분을 생 성함으로써 쓴맛을 감소시켜 기호성을 높여 주는 것으로 보 고되어 있다(Cho and Joo, 2012). 침출차에 대한 대중의 관심 이 높아지면서 여주(Ahn 등, 2015), 옥수수(Lee 등, 2017) 및 옻씨(Jin 등, 2017) 등과 같이 다양한 식물체를 온도와 시간 에 따른 볶음 처리 연구가 진행되었고 이러한 공정은 항산화 활성과 총 폴리페놀 함량 등에 영향을 주는 것으로 보고되었 다. 이러한 천연 재료를 볶음 처리하여 기호성과 상품성을 증 진시키는 다양한 연구가 진행되고 있다. 따라서, 본 연구에서 는 새싹인삼의 볶음 횟수가 증가함에 따라 변화되는 이화학 적 특성, 총 phenolics와 총 flavonoids, 갈변물질, ginsenosides, phenolic acids, flavonols 함량 및 항산화 활성 등의 최 적 조건을 분석하였다.

\section{재료 및 방법}

\section{실험재료, 시약 및 기기}

새싹인삼은 경상남도 사천시 서포면 소재 농업회사법인 드림팜의 식물공장에서 재배된 것을 공급받아 사용하였다. 온도 $17 \pm 2^{\circ} \mathrm{C}$, 습도 $95 \pm 2 \%$, 및 LED 광원(적색, 청색과 백색 혼합 광원) $400 \pm 2001 x$ 로 자동 제어된 식물공장에서 30 일간 재배된 새싹인삼을 공급받아 사용하였다. 공급받은 새싹인삼 은 큰 줄기에서 두 줄기로 나누어져 각각 줄기에서 잎이 5 개 생성되었고, 지상부(잎과 줄기)와 지하부(뿌리)의 평균 길이는 각각 $19.52 \mathrm{~cm}$ 와 $13.11 \mathrm{~cm}$ 였고 평균 무게는 각각 $1.4 \mathrm{~g}$ 과 $0.9 \mathrm{~g}$ 이었다. 21 종의 ginsenosides 표준품 $(\mathrm{Rb} 1, \mathrm{Re}, \mathrm{Ro}$, $\mathrm{Rg} 2, \mathrm{Rg} 3, \mathrm{Rb} 2, \mathrm{Rd}, \mathrm{F} 2$ 및 compound $\mathrm{K}$ 등)은 $\mathrm{KOC}$ 바이오 텍(Daejeon, Korea)에서 구입하였다. Phenolic acids 표준품 (gallic acid, chlorogenic acid, protocatechuic acid, vanillic acid, ferulic acid 및 ventaric acid)과 flavonols 표준품 (epigallocatechin, catechin, vanilin, rutin, catechin gallate, quercetin 및 formonoetin)은 Sigma-Aldrich 사에서 구입하였
다. 총 phenolics 측정에 사용된 Folin-Cicalteu phenol과 총 flavonoids 함량 측정에 사용된 diethyleneglycol은 SigmaAldrich(St. Louis, MO, USA)에서 구입하여 사용하였다. 항 산화 활성에 사용된 2,2'-diphenyl-1-picrylhydrazyl(DPPH), 2,4,6-azino-bis(3-ethylbenzothiazoline-6-sulphnoic acid) diammonium salt(ABTS), thiobarbituric acid(TBA) 및 trichloroacetic acid(TCA) 역시 Sigma-Aldrich Co.에서 구입하여 사 용하였다. HPLC-grad water, acetonitrile 및 methanol은 Fisher Scientific(Fairlawn, NJ, USA)에서 구입하였고, 이외 분석에 사용된 시약은 1 급으로 구입하여 실험에 사용하였다.

\section{새싹인삼의 볶음처리}

새싹인삼은 3 회 세척하고 물기를 제거하고 지상부(잎과 줄 기)와 지하부(뿌리)로 구분한 후 $100^{\circ} \mathrm{C}$ 에서 10 분간 증자하였 다. 지상부는 $150^{\circ} \mathrm{C}$ 에서 5 분간 1,2 및 3 회 볶음 처리하였고, 지하부는 $200^{\circ} \mathrm{C}$ 에서 5 분간 1,2 및 3 회 볶음 처리하였다(Fig. 1). 볶음 처리한 시료는 분쇄 후 사용 전까지 $-20^{\circ} \mathrm{C}$ 에서 보관 하였다.

\section{$\mathrm{pH}$, 산도 및 환원당 측정}

$\mathrm{pH}$ 는 분쇄한 부위별 및 횟수별 시료 $1 \mathrm{~g}$ 을 증류수로 10 배 진탕하여 pH meter(MP $200 \mathrm{pH}$ meter, Schwerzenbach, UK) 를 사용하여 측정하였다. 산도는 각각의 시료 $1 \mathrm{~g}$ 에 증류수 $50 \mathrm{~mL}$ 를 가하여 현탁 시킨 후 그 상등액을 $0.1 \mathrm{~N} \mathrm{NaOH}$ 로 $\mathrm{pH} 8.20$ 까지 적정하여 그 소모량을 젖산량으로 환산하여 \% 로 나타내었다.

$$
\begin{aligned}
& \text { 산도 }(\%, \text { 젖산 })= 0.009 \times \mathrm{mL} \text { of } 0.1 \mathrm{~N} \mathrm{NaOH} \times \mathrm{F} \times 100 \\
& / \text { 시료량 }(\mathrm{g})
\end{aligned}
$$

F: factor of $0.1 \mathrm{~N} \mathrm{NaOH}$

환원당 함량은 각각의 시료 $1 \mathrm{~g}$ 에 10 배의 증류수를 가한 것을 사용하였다. 즉, 각각의 시료 현탁물 $0.1 \mathrm{~mL}$ 에 $\mathrm{DNS}$ (dinitro salictlic acid) 시약 $1 \mathrm{~mL}$ 를 가하여 $100^{\circ} \mathrm{C}$ 에서 20 분 간 발색시키고, 냉각시킨 후 $570 \mathrm{~nm}$ 에서 흡광도를 측정하였 다. 환원당 표준 물질은 glucose를 사용하여 작성된 표준 검 량곡선으로부터 값을 산출하였다.

\section{지방산 분석}

지방산 분석은 Cho 등(2017)의 방법을 약간 변형하여 gas chromatograph(GC, Agilent 7890A system, Agilent Technologies Inc., Wilmington, DE, USA)를 사용하여 측정하였 다. 시료 $1 \mathrm{~g}$ 을 시험관에 정확히 칭량하고 $0.5 \mathrm{~N}$ 메탄올성 $\mathrm{NaOH}$ 를 $3 \mathrm{~mL}$ 분주한 후 $100^{\circ} \mathrm{C}$ 에서 10 분간 열처리하여 지 


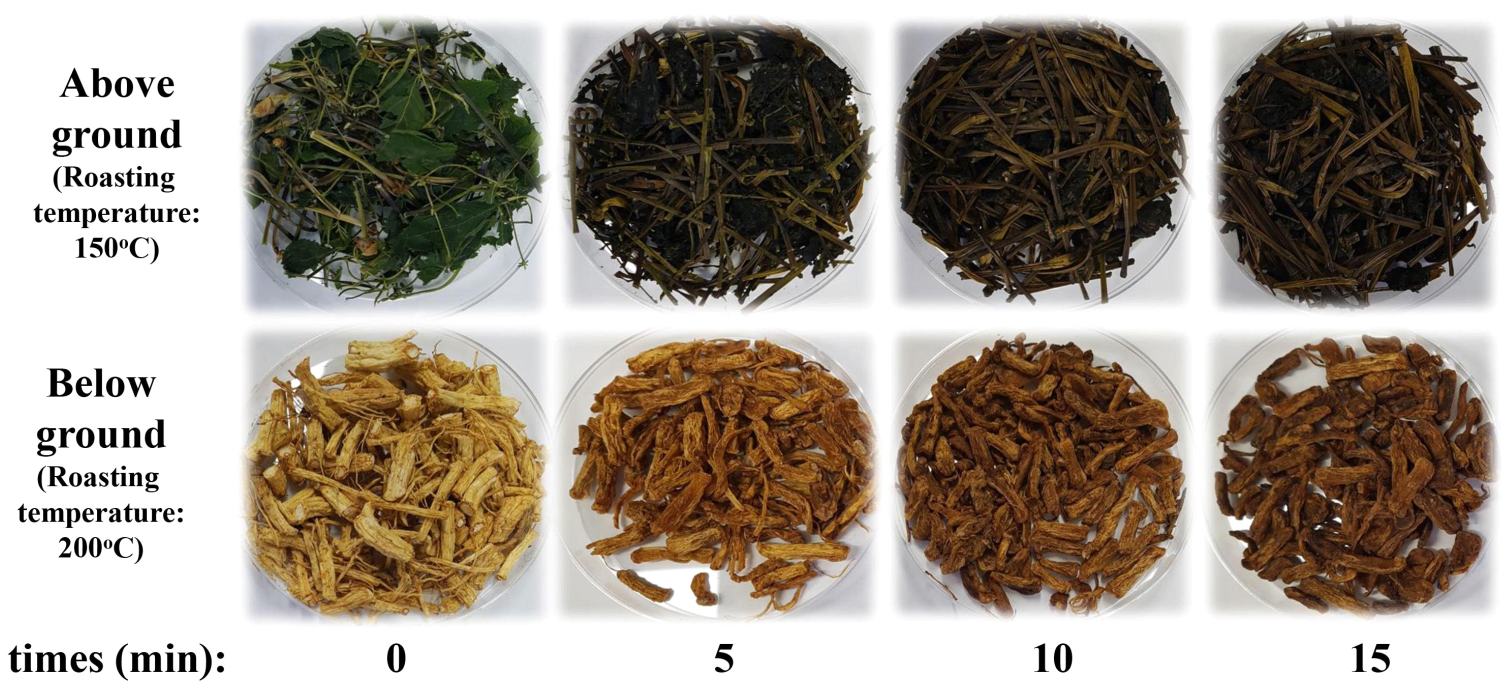

Fig. 1. The photograph of different roasting processes of ginseng sprouts.

방산과 글리세롤 가수분해한 후 삼불화붕소(BF3) $2 \mathrm{~mL}$ 를 첨 가하고 교반한 후 다시 30 분간 열처리하여 지방산의 메틸에 스테르화를 진행하였다. 메틸에스테르화 반응이 끝난 후 이 소옥탄 $1 \mathrm{~mL}$ 를 첨가하고, 혼합 및 방치시켜 이소옥탄층만을 회수하여 무수황산나트륨과 함께 탈수한 뒤 $0.45 \mu \mathrm{m}$ membrane filter로 여과하여 $\mathrm{GC}$ 로 분석하였다. 이동상은 질소 가 스를 사용하였으며, 속도는 $1 \mathrm{~mL} / \mathrm{min}$ 으로 유지하였다. 오븐 의 온도는 $140^{\circ} \mathrm{C}$ 에서 5 분간 유지한 후 1 분당 $20^{\circ} \mathrm{C}$ 만큼 상승 시켜 $180^{\circ} \mathrm{C}$ 에서 2 분간 유지하였고, $5^{\circ} \mathrm{C}$ 만큼 상승시켜 $230^{\circ} \mathrm{C}$ 까지 온도를 올려 35 분간 유지하였다. Injector 온도는 $220^{\circ} \mathrm{C}$ 로 하였고, FID detector의 온도는 $240^{\circ} \mathrm{C}$ 로 하였다.

\section{유리아미노산 분석}

유리아미노산 분석은 시료 $1 \mathrm{~g}$ 에 증류수 $4 \mathrm{~mL}$ 를 가하여 교 반하였다. $60{ }^{\circ} \mathrm{C}$ 에서 1 시간 가수분해한 후 $10 \% 5$-sulfosalicylic acid $1 \mathrm{~mL}$ 를 첨가하여 $4^{\circ} \mathrm{C}$ 에서 2 시간 방치시켜 단백질을 침 전시킨다. 3 분간 원심분리하여 얻은 상등액을 $0.45 \mu \mathrm{m}$ membrane filter(Dismic-25CS, Toyoroshikaisha Ltd., Tokyo, $\mathrm{Japan}$ )로 1 차 여과시켜 $60^{\circ} \mathrm{C}$ 에서 감압 농축하였다. 농축된 시 료는 lithium citrate buffer(pH 2.2) $2 \mathrm{~mL}$ 에 용해 후 $0.45 \mu \mathrm{m}$ membrane filter로 여과한 여액을 아미노산 자동분석기 (L-8900, Hitachi High-Technologies Corp., Tokyo, Japan)를 이용하여 분석하였다.

\section{무기질 분석}

무기질 분석은 시료 $0.5 \mathrm{~g}$ 을 시험관에 칭량하고, 여기에 $70 \%$ 질산 용액을 $10 \mathrm{~mL}$ 첨가하여 microwave high pressure digestion system(Ultrawave 2.0, Milestone, Bergamo, Italy) 로 분해하였다. 분해 후 최종 부피가 $50 \mathrm{~mL}$ 가 되도록 증류수 로 정용하여 liquid chromatography-inductively coupled plasma mass spectrometer(NexION 350 ICP MS, PerkinElmer Inc., Waltham, USA)로 분석하였다.

\section{총 phenolics, 총 flavonoids 및 갈변물질 분석}

총 phenolics와 총 flavonoids 함량 분석을 위한 추출은 분 쇄한 시료 $1 \mathrm{~g}$ 에 50\% 발효 주정(I1-San Trading Co., Ltd., Haman, Korea) $10 \mathrm{~mL}$ 를 분주하여 상온에서 12시간 동안 추 출하여 원심분리한 후 상등액을 $0.45 \mu \mathrm{m}$ membrane filter (Dismic-25CS, Toyotoshikaisha Ltd., Tokyo, Japan)로 여과 하여 추출물을 제조하였다. 총 phenolics 함량은 희석된 시료 와 $25 \% \mathrm{Na}_{2} \mathrm{CO}_{3}$ 용액을 각각 $0.5 \mathrm{~mL}$ 씩 시험관에 분주하여 3 분간 정치시킨 후 $2 \mathrm{~N}$ Folin-Ciocalteu phenol 시약 0.25 $\mathrm{mL}$ 첨가 후 흔들어 $30^{\circ} \mathrm{C}$ 에서 1 시간 발색시킨 후 분광 광도 계(UV-1800 240V, Shimadzu Corp., Kyoto, Japan)를 사용하 여 $750 \mathrm{~nm}$ 에서 측정하였고 gallic acid를 이용하여 작성된 표 준 검량곡선에 대입하여 값을 계산하였다. 총 flavonoids 함 량은 추출물 $0.5 \mathrm{~mL}$ 를 시험관에 분주하고, diethylene glycol 용액 $1 \mathrm{~mL}$ 와 $1 \mathrm{~N} \mathrm{NaOH} 0.01 \mathrm{~mL}$ 를 첨가한 후 수욕상 $\left(37^{\circ} \mathrm{C}\right)$ 에서 1시간 반응시킨 후 $420 \mathrm{~nm}(\mathrm{UV}-1800240 \mathrm{~V}$, Shimadzu Corp.)로 측정하였으며, Rutin을 이용하여 작성된 표준 검량 곡선으로부터 함량을 계산하였다. 갈변물질은 시료 $1 \mathrm{~g}$ 에 증 류수를 $10 \mathrm{~mL}$ 가한 후 1 시간 동안 교반한 후 원심분리하여 상등액을 취하여 $420 \mathrm{~nm}(\mathrm{UV}-1800$ 240V, Shimadzu Corp.) 에서 측정하였다. 


\section{Ginsenosides 유도체 분석}

Ginsenosides 유도체 분석은 Jin 등(2012)의 방법을 약간 변형하여 high performance liquid chromatography(HPLC, Agilent 1260 system, Agilent Technologies Inc., Waldbronn, Germany)를 이용하여 실시하였다. 분쇄된 시료 $1 \mathrm{~g}$ 에 HPLC water $20 \mathrm{~mL}$ 를 가하여 항온수조 $\left(70^{\circ} \mathrm{C}\right)$ 에서 1 시간 추출하였 고, 이를 원심분리하여 $0.45 \mu \mathrm{m}$ membrane filter로 여과하였 다. 이를 2 회 반복하여 얻은 추출물을 $60^{\circ} \mathrm{C}$ 에서 감압농축 후 HPLC water $2 \mathrm{~mL}$ 로 용해하여 $0.45 \mu \mathrm{m}$ membrane filter로 여과한 여액을 분석 시료로 사용하였다. 시료 주입량은 $10 \mu \mathrm{L}$, 유속은 $1.0 \mathrm{~mL} / \mathrm{min}$ 을 유지하였고, 칼럼은 TSKgel ODS$100 Z$ 를 사용하였다. 이동상 용매는 HPLC water(A 용매)와 HPLC acetonitrile(B 용매)로 사용하였으며, 분석 조건은 A 용매 기준으로 $10 \mathrm{~min}-81 \%, 15 \mathrm{~min}-80 \%, 40 \mathrm{~min}-77 \%, 75$ $\min -65 \%, 90 \mathrm{~min}-10 \% 105 \mathrm{~min}-81 \%$ 를 바탕으로 하여 203 $\mathrm{nm}$ 에서 분석하였다.

\section{Phenolic acids 및 flavonols 유도체 분석}

Phenolic acids 및 flavonols 유도체 분석은 Hwang 등 (2017)의 방법을 약간 변형하여 HPLC(Agilent 1260 system, Agilent Technologies Inc.)로 분석하였다. XBridge ${ }^{\mathrm{TM}} \mathrm{C} 18$ 칼 럼을 사용하였고, 칼럼 온도는 $30^{\circ} \mathrm{C}$, 시료 주입량은 $10 \mu \mathrm{L}$, 유속은 분당 $1 \mathrm{~mL}$ 를 유지하였다. 분석용매는 $0.2 \%$ acetic acid in HPLC water(A용매) 및 $0.2 \%$ acetic acid in acetonitrile(B용매)를 사용하였으며 이동상 조건은 B 용매 기준으로 0 min- $0 \%$, 3 min-3\%, 5 min-5\%, 8 min-10\%, 10 min- $15 \%$, $15 \min -5 \%, 17 \min -8 \%, 19 \min -10 \%, 20 \min -15 \%, 22$ $\min -20 \%$, $26 \min -15 \%, 27 \min -20 \%, 28 \min -30 \%, 32$ $\min -40 \%, 36 \min -60 \%, 37 \min -30 \%, 38 \min 40 \%, 40$ $\min -50 \%, 45 \min -60 \%$, $55 \mathrm{~min}-80 \%, 60 \mathrm{~min}-90 \%$ 및 65 $\min -100 \%$ 로 유지하였다. 한편, 각각 phenolic acids 유도체 는 $280 \mathrm{~nm}$ 및 flavonols 유도체는 $270 \mathrm{~nm}$ 에서 분석하였다.

\section{항산화 능력 측정}

DPPH 라디칼 소거활성은 Hwang 등(2013)의 방법에 따라 측정하였다. $\mathrm{DPPH}$ 용액 $0.8 \mathrm{~mL}$ 를 시험관에 분주하고 적당 히 희석한 시료 $0.2 \mathrm{~mL}$ 를 가하여 10 초간 교반한 후 실온에서 30 분간 반응시킨 후 분광광도계를 이용하여 $525 \mathrm{~nm}(\mathrm{UV}$ 1800 240V, Shimadzu Corp.)에서 측정하였다. ABTS 라디칼 소거활성 역시 Hwang 등(2013)의 방법에 따라 측정하였다. $7 \mathrm{mM} \mathrm{ABTS}$ 용액과 $2.45 \mathrm{mM}$ potassuim persulfate 용액을 1:1로 섞어 실온 암실에서 12-16시간 반응하여 $\mathrm{ABTS}^{++}$ radical을 형성시킨 후 $732 \mathrm{~nm}(\mathrm{UV}-1800$ 240V, Shimadzu Corp.)에서 흡광도 값이 $0.7 \pm 0.02$ 가 되도록 메탄올로 희석하
였고, 희석된 $\mathrm{ABTS}$ 용액 $0.9 \mathrm{~mL}$ 와 시료 $0.1 \mathrm{~mL}$ 를 시험관에 분주하여 정확히 3 분 후에 측정하였다. Hydroxyl 라디칼 소거 활성은 $\mathrm{Ahn}$ 등(2015)의 방법에 따라 측정하였다. $10 \mathrm{mM}$ $\mathrm{H}_{2} \mathrm{O}_{2}, 10 \mathrm{mM} \mathrm{FeSO}_{4} \cdot 7 \mathrm{H}_{2} \mathrm{O}$-EDTA, 및 $10 \mathrm{mM}$ 2-deoxyribose $0.2 \mathrm{~mL}$ 를 시험관에 분주하고, 시료 $1.4 \mathrm{~mL}$ 를 가하여 $37^{\circ} \mathrm{C}$ 에 서 4 시간 동안 반응시켰다. 이후 $1 \% \mathrm{TBA}$ 와 $2.8 \% \mathrm{TCA} 1$ $\mathrm{mL}$ 를 분주하고 $100^{\circ} \mathrm{C}$ 에서 20 분 발색한 후 $520 \mathrm{~nm}(\mathrm{UV}-1800$ $240 \mathrm{~V}$, Shimadzu Corp.)에서 측정하였다. 음성대조구는 시료 대신 PBS 완충용액을 사용하였으며, 시료 첨가구와 무첨가 구 사이의 차이를 백분율(\%)로 나타내었다.

\section{라디칼 소거활성 $(\%)=(1$ - 음성대조구 흡광도 / 첨가구 흡광도) $\times 100$}

FRAP 환원력 측정은 Hwang 등(2014)의 방법을 조금 변 형하여 측정하였다. $30 \mathrm{mM}$ acetate buffer(pH 3.6), $10 \mathrm{mM}$ $\mathrm{TPTZ}$ 시약 $(40 \mathrm{mM} \mathrm{HCl})$ 및 $20 \mathrm{mM} \mathrm{FeCl}$ 용액을 10:1:1 $(\mathrm{v} / \mathrm{v} / \mathrm{v})$ 의 비율로 혼합하여 FRAP 측정 시약을 조제하였다. 시료 $50 \mu \mathrm{L}$ 와 $37^{\circ} \mathrm{C}$ 항온기에서 15 분 예비 반응한 FRAP 시 약 $950 \mu \mathrm{L}$ 를 시험관에 분주하여 $37^{\circ} \mathrm{C}$ 에서 15 분 반응시키고, 분광 광도계를 사용하여 $593 \mathrm{~nm}(\mathrm{UV}-1800$ 240V, Shimadzu Corp.)에서 흡광도를 측정하였다. 각 실험은 3 회 반복하여 평 균 \pm 표준편차로 나타내었다.

\section{결과 및 고찰}

\section{볶음 처리에 따른 새싹인삼의 $\mathrm{pH}$, 산도 및 환원당 변화}

새싹인삼의 볶음 처리에 따른 이화학적 특성은 Table 1 과 같았다. 지상부의 원료에서 $\mathrm{pH}$ 는 5.72로 나타났으며, 볶음 처리 시간이 증가할수록 $\mathrm{pH}$ 는 낮아져 15 분 볶음 처리하였을 때 5.50로 나타났다. 또한 지하부의 $\mathrm{pH}$ 의 변화는 원료 5.81 에서 15 분 볶음 처리하였을 때 5.55 로 낮아졌다. 산도는 지상 부의 원료에서 $3.78 \%$ 로 가장 높게 나타났으며 볶음 처리하 였을 때 산도가 낮아졌으나, 붂음 시간이 증가할수록 산도 또 한 증가하였다. 지하부의 산도는 원료에서 $3.22 \%$ 로 높은 수 치를 나타냈으며, 15 분 볶음 처리하였을 때 $2.43 \%$ 로 가장 낮 게 나타났다. 지상부의 환원당은 원료일 때보다 볶음 처리 시 간이 5 분, 10 분 및 15 분으로 증가할수록 함량은 각각 3.40 $\mathrm{mg} / \mathrm{g}$ 에서 4.80, 4.55 및 $9.56 \mathrm{mg} / \mathrm{g}$ 으로 원료에 비해 증가하 였다. 지하부의 경우 원료에서 $9.44 \mathrm{mg} / \mathrm{g}$ 에서 5 분 볶음 처리 하였을 때 $8.33 \mathrm{mg} / \mathrm{g}$ 으로 약간 감소하였으나, 볶음 처리 시 간이 10 분 및 15 분으로 증가할수록 함량 또한 $16.57 \mathrm{mg} / \mathrm{g}$ 및 $14.23 \mathrm{mg} / \mathrm{g}$ 으로 증가하였다. Park 등(1993)은 온도 변화 에 따라 인삼을 볶음 처리하여 비교하였을 때 원료에서 5.36 
Table 1. Comparison of physicochemical properties of ginseng sprouts (above and below ground) according to roasting process

\begin{tabular}{|c|c|c|c|c|c|c|c|c|}
\hline \multirow{2}{*}{ Contents } & \multicolumn{4}{|c|}{ Above ground / Roasting time } & \multicolumn{4}{|c|}{ Below ground / Roasting time } \\
\hline & 0 & 5 & 10 & 15 & 0 & 5 & 10 & 15 \\
\hline $\mathrm{pH}$ & $5.72 \pm 0.29^{\mathrm{al})}$ & $5.64 \pm 0.28^{\mathrm{a}}$ & $5.58 \pm 0.28^{\mathrm{a}}$ & $5.50 \pm 0.28^{\mathrm{a}}$ & $5.81 \pm 0.29^{\mathrm{a}}$ & $5.7 \pm 0.29^{\mathrm{a}}$ & $5.58 \pm 0.28^{\mathrm{a}}$ & $5.55 \pm 0.28^{\mathrm{a}}$ \\
\hline Acidity (\%, lactic acid) & $3.78 \pm 0.19^{\mathrm{a}}$ & $2.95 \pm 0.15^{\mathrm{b}}$ & $2.97 \pm 0.15^{\mathrm{b}}$ & $3.01 \pm 0.15^{\mathrm{b}}$ & $3.22 \pm 0.16^{\mathrm{ab}}$ & $2.55 \pm 0.13^{\mathrm{c}}$ & $2.63 \pm 0.13^{\mathrm{c}}$ & $2.43 \pm 0.12^{\mathrm{c}}$ \\
\hline Reducing sugar (mg/g d.w.) & $3.40 \pm 0.17^{\mathrm{c}}$ & $4.80 \pm 0.24^{\mathrm{c}}$ & $4.55 \pm 0.23^{\mathrm{c}}$ & $9.56 \pm 0.48^{\mathrm{b}}$ & $9.44 \pm 0.47^{\mathrm{b}}$ & $8.33 \pm 0.42^{\mathrm{b}}$ & $16.57 \pm 0.83^{\mathrm{a}}$ & $14.23 \pm 0.71^{\mathrm{ab}}$ \\
\hline
\end{tabular}

${ }^{1)}$ All values are presented as the mean $\pm \mathrm{SD}$ of triplicate determinations. All values within a column with different superscript letters represent statistically significant difference from each other at $\mathrm{p}<0.05$ by Duncan's multiple range test.

에서 4.67로 $\mathrm{pH}$ 가 낮아졌다고 보고하였다. 또한, 볶음처리와 같은 원료에 가열을 하였을 때 $\mathrm{pH}$ 가 저하되는 원인은 비효소 적 갈변 반응이 발생될 때 생성되는 전구물질인 carbonyl compounds의 작용에 의해 생성되는 유기산에 의한 것이라 판단하였다.

\section{볶음 처리에 따른 새싹인삼의 지방산 변화}

새싹인삼의 볶음 처리에 따른 지방산 함량 비교는 Table 2 와 같았다. 지상부의 포화지방산 중 palmitic acid(C16:0), stearic $\operatorname{acid}(\mathrm{C} 18: 0)$ 및 myristic $\operatorname{acid}(\mathrm{C} 14: 0)$ 의 함량이 높았다. 볶음 처리 시간이 증가할수록 palmitic acid의 함량은 원료일 때 $261.8 \mathrm{mg} / 100 \mathrm{~g}$ 에서 15 분간 볶음 처리하였을 때 191.4 $\mathrm{mg} / 100 \mathrm{~g}$ 으로 함량이 감소하는 것을 보였다. Stearic acid 또 한 원료일 때 $96.7 \mathrm{mg} / 100 \mathrm{~g}$ 으로 나타났으나, 15 분 볶음 처리 시 $86.0 \mathrm{mg} / 100 \mathrm{~g}$ 으로 함량이 감소하였다. Lignoceric acid (C24:0)의 경우 0 분 처리 시 검출되지 않았으나, 볶음 처리가 진행됨에 따라 $4.3 \mathrm{mg} / 100 \mathrm{~g}, 6.4 \mathrm{mg} / 100 \mathrm{~g}$ 및 $7.9 \mathrm{mg} / 100$ $\mathrm{g}$ 으로 증가하였다. 불포화지방산 중 linoleic $\operatorname{acid}(\mathrm{C} 18: 2 \mathrm{c})$ 의 함량이 가장 높았으며, 볶음 처리에 따라 큰 차이를 보이지 않았다. Palmitoleic $\operatorname{acid}(\mathrm{C} 16: 1)$ 의 경우, 볶음 처리 시간이 증 가할수록 $7.4 \mathrm{mg} / 100 \mathrm{~g}, 8.3 \mathrm{mg} / 100 \mathrm{~g}, 10.2 \mathrm{mg} / 100 \mathrm{~g}$ 및 $12.3 \mathrm{mg} / 100 \mathrm{~g}$ 으로 함량이 증가하였다. $\alpha$-Linolenic acid $(\mathrm{C} 18: 3 \mathrm{n} 3)$ 의 경우, 0 분 처리 시 $186.0 \mathrm{mg} / 100 \mathrm{~g}$ 의 함량을 보 였으나, 볶음 처리가 진행되면서 $295.9 \mathrm{mg} / 100 \mathrm{~g}, 278.1$ $\mathrm{mg} / 100 \mathrm{~g}$ 및 $257.8 \mathrm{mg} / 100 \mathrm{~g}$ 으로 함량이 증가하였으며, 볶 음 처리에 따른 큰 차이는 없었다. 지하부의 경우 myristic acid는 검출되지 않았으며, palmitic acid의 경우 볶음 처리 시간이 증가하여도 큰 차이를 보이지 않았으나, 볶음 처리를 15 분간 진행되었을 때 $166.5 \mathrm{mg} / 100 \mathrm{~g}$ 으로 가장 낮은 함량 을 보였다. Arachidic $\operatorname{acid}(\mathrm{C} 20: 4 \mathrm{n} 6)$ 는 지하부에선 검출되었 으며, 볶음 처리에 따라 $6.1 \mathrm{mg} / 100 \mathrm{~g}, 6.3 \mathrm{mg} / 100 \mathrm{~g}, 7.0$ $\mathrm{mg} / 100 \mathrm{~g}$ 및 $5.4 \mathrm{mg} / 100 \mathrm{~g}$ 으로 큰 차이는 보이지 않았다. 불포화지방산 중 linoleic acid는 볶음 처리 시간이 증가함에 따라 0 분 $(291.7 \mathrm{mg} / 100 \mathrm{~g}), 5$ 분 $(297.8 \mathrm{mg} / 100 \mathrm{~g}), 10$ 분(302.2 $\mathrm{mg} / 100 \mathrm{~g})$ 및 15 분 $(312.8 \mathrm{mg} / 100 \mathrm{~g})$ 으로 함량 역시 증가하 였다. Ecosadienoic acid(C20:2)는 10분간 볶음 처리 시 5.5 $\mathrm{mg} / 100 \mathrm{~g}$ 으로 가장 높은 함량을 보였으나 유의적 차이를 보 이지 않았다.

Jang 등(2018)은 햄프씨드의 가열 처리에 따른 지방산 함 량을 분석하였다. 그 결과, 포화지방산의 함량은 $2,935.60$ $\mathrm{mg} \%$ 의 함량에서 볶음 처리하였을 때 $3,164.29 \mathrm{mg} / \%$ 로 증 가하였고, 불포화지방산의 함량은 원료 $39,437.51 \mathrm{mg} \%$ 에서 $40,733.91 \mathrm{mg} \%$ 로 증가하는 것을 보였다. 이에 다른 시료들 과 볶음 처리와 비교하였을 때 지방산 함량과 조성은 시료와 시료의 지방산의 조성에 따라 차이가 있는 것으로 예상하였 으며, 이에 따른 함량의 증감 차이가 있다고 보고하였다. 본 연구에서는 포화지방산의 함량은 볶음 처리하였을 때 원료에 비해 낮아졌고, 불포화지방산의 함량은 증가하여 시료에 따 른 지방산 조성의 차이가 있는 것으로 판단된다.

\section{볶음 처리에 따른 새싹인삼의 유리아미노산 변화}

새싹인삼의 볶음 처리에 따른 지상부 및 지하부의 유리아 미노산은 Table 3 과 같았다. 지상부의 경우, aspartic acid의 함량은 5 분 볶음 처리하였을 때 $162.26 \mathrm{mg} / 100 \mathrm{~g}$ 으로 가장 높게 나타났으며, 15 분 볶음 처리하였을 때 $119.34 \mathrm{mg} / 100$ $\mathrm{g}$ 으로 가장 낮은 함량을 보였다. Glutamic acid 또한 5 분 볶 았을 때 $107.55 \mathrm{mg} / 100 \mathrm{~g}$ 의 함량으로 가장 높았으며, 10 분 볶음 처리하였을 때는 $100.01 \mathrm{mg} / 100 \mathrm{~g}$ 으로 큰 차이를 보이 지 않았다. $\gamma$-Aminobutyric acid 및 대부분의 비필수 유리아 미노산의 경우, 볶음 시간이 증가할수록 함량이 감소하는 것 으로 나타났다. 필수 아미노산의 경우에도 원료일 때보다 볶 음 시간이 증가함에 따라 함량이 감소하는 것으로 나타났다. 지하부의 경우 aspartic acid의 함량이 원료일 때 89.29 $\mathrm{mg} / 100 \mathrm{~g}$ 의 함량을 보였으며, 15 분 볶았을 때 136.69 $\mathrm{mg} / 100 \mathrm{~g}$ 으로 볶음 처리를 하였을 때 함량이 증가하였다. Alanine의 경우, 볶음 처리를 하지 않았을 때 $106.76 \mathrm{mg} / 100$ $\mathrm{g}$ 의 함량을 보였으나, 15 분간 볶음 처리하였을 때 31.11 $\mathrm{mg} / 100 \mathrm{~g}$ 으로 함량이 감소하는 것을 보였다. 또한 기타 비 
Table 2. Comprehensive changes of fatty acid contents of ginseng sprouts (above and below ground) according to the roasting process

\begin{tabular}{|c|c|c|c|c|c|c|c|c|}
\hline \multirow{2}{*}{ Contents (mg/100 g) } & \multicolumn{4}{|c|}{ Above ground / Roasting time $\left(\mathrm{min}, 150^{\circ} \mathrm{C}\right)$} & \multicolumn{4}{|c|}{ Below ground / Roasting time $\left(\min , 200^{\circ} \mathrm{C}\right)$} \\
\hline & 0 & 5 & 10 & 15 & 0 & 5 & 10 & 15 \\
\hline \multicolumn{9}{|l|}{ Saturated fatty acids } \\
\hline Myristic acid (C14:0) & $\begin{array}{c}5.1 \\
\pm 0.26^{\text {al })}\end{array}$ & $\begin{array}{c}4.7 \\
\pm 0.24^{\mathrm{a}}\end{array}$ & $\begin{array}{c}5.0 \\
\pm 0.25^{\mathrm{a}}\end{array}$ & $\begin{array}{c}4.9 \\
\pm 0.25^{\mathrm{a}}\end{array}$ & $\mathrm{ND}^{2)}$ & ND & ND & ND \\
\hline Palmitic acid (C16:0) & $\begin{array}{c}261.8 \\
\pm 13.09^{\mathrm{a}}\end{array}$ & $\begin{array}{c}250.5 \\
\pm 12.53^{\mathrm{a}}\end{array}$ & $\begin{array}{c}200.3 \\
\pm 10.02^{\mathrm{b}}\end{array}$ & $\begin{array}{c}191.4 \\
\pm 9.57^{\mathrm{b}}\end{array}$ & $\begin{array}{c}182.4 \\
\pm 9.12^{\mathrm{bc}}\end{array}$ & $\begin{array}{c}185.5 \\
\pm 9.28^{\mathrm{bc}}\end{array}$ & $\begin{array}{c}184.7 \\
\pm 9.24^{\mathrm{bc}}\end{array}$ & $\begin{array}{l}166.5 \\
\pm 8.33^{\mathrm{c}}\end{array}$ \\
\hline Stearic acid $(\mathrm{C} 18: 0)$ & $\begin{array}{c}96.7 \\
\pm 4.84^{\mathrm{a}}\end{array}$ & $\begin{array}{c}87.9 \\
\pm 4.40^{\mathrm{b}}\end{array}$ & $\begin{array}{c}87.0 \\
\pm 4.35^{\mathrm{b}}\end{array}$ & $\begin{array}{c}86.0 \\
\pm 4.30^{\mathrm{b}}\end{array}$ & $\begin{array}{c}89.7 \\
\pm 4.49^{\mathrm{ab}}\end{array}$ & $\begin{array}{c}78.4 \\
\pm 3.92^{\mathrm{c}}\end{array}$ & $\begin{array}{c}78.2 \\
\pm 3.91^{\mathrm{c}}\end{array}$ & $\begin{array}{c}71.6 \\
\pm 3.58^{\mathrm{c}}\end{array}$ \\
\hline Arachidic acid (C20:0) & ND & ND & ND & ND & $\begin{array}{c}6.1 \\
\pm 0.31^{\mathrm{ab}}\end{array}$ & $\begin{array}{c}6.3 \\
\pm 0.32^{\mathrm{ab}}\end{array}$ & $\begin{array}{c}7.0 \\
\pm 0.35^{\mathrm{a}}\end{array}$ & $\begin{array}{c}5.4 \\
\pm 0.27^{\mathrm{b}}\end{array}$ \\
\hline Behenic aicd (C22:0) & $\begin{array}{c}5.4 \\
\pm 0.27^{\mathrm{c}}\end{array}$ & $\begin{array}{c}4.9 \\
\pm 0.25^{\mathrm{c}}\end{array}$ & $\begin{array}{c}6.8 \\
\pm 0.34^{\mathrm{c}}\end{array}$ & $\begin{array}{c}5.5 \\
\pm 0.28^{\mathrm{c}}\end{array}$ & $\begin{array}{c}11.0 \\
\pm 0.55^{\mathrm{b}}\end{array}$ & $\begin{array}{c}11.5 \\
\pm 0.58^{b}\end{array}$ & $\begin{array}{c}13.4 \\
\pm 0.67^{\mathrm{a}}\end{array}$ & $\begin{array}{c}10.4 \\
\pm 0.52^{\mathrm{b}}\end{array}$ \\
\hline Lignoceric acid (C24:0) & ND & $\begin{array}{c}4.3 \\
\pm 0.22^{\mathrm{c}}\end{array}$ & 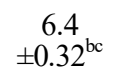 & $\begin{array}{c}7.9 \\
\pm 0.40^{\mathrm{b}}\end{array}$ & $\begin{array}{c}8.3 \\
\pm 0.42^{\mathrm{b}}\end{array}$ & $\begin{array}{c}7.9 \\
\pm 0.40^{\mathrm{b}}\end{array}$ & $\begin{array}{c}8.6 \\
\pm 0.43^{\mathrm{b}}\end{array}$ & $\begin{array}{c}12.2 \\
\pm 0.61^{\mathrm{a}}\end{array}$ \\
\hline Total & 369.0 & 352.3 & 305.5 & 295.7 & 297.5 & 289.6 & 291.9 & 266.1 \\
\hline \multicolumn{9}{|l|}{ Unsaturated fatty acids } \\
\hline Palmitoleic acid (C16:1) & $\begin{array}{c}7.4 \\
\pm 0.37^{\mathrm{b}}\end{array}$ & $\begin{array}{c}8.3 \\
\pm 0.42^{\mathrm{b}}\end{array}$ & $\begin{array}{l}10.2 \\
\pm 0.51^{\mathrm{ab}}\end{array}$ & $\begin{array}{c}12.3 \\
\pm 0.62^{\mathrm{a}}\end{array}$ & ND & ND & ND & ND \\
\hline Oleic acid (C18:1c) & $\begin{array}{c}84.8 \\
\pm 4.24^{\mathrm{a}}\end{array}$ & $\begin{aligned} & 44.2 \\
\pm & 2.21^{\mathrm{b}}\end{aligned}$ & $\begin{array}{c} \\
46.4 \\
\pm 2.32^{\mathrm{b}}\end{array}$ & $\begin{aligned} & 43.5 \\
\pm & 2.18^{\mathrm{b}}\end{aligned}$ & $\begin{array}{c}19.3 \\
\pm 0.97^{\mathrm{c}}\end{array}$ & $\begin{array}{c}24.4 \\
\pm 1.22^{\mathrm{c}}\end{array}$ & $\begin{array}{c}22.8 \\
\pm 1.14^{\mathrm{c}}\end{array}$ & $\begin{array}{c}22.3 \\
\pm 1.12^{\mathrm{c}}\end{array}$ \\
\hline Linoleic acid (C18:2c) & $\begin{array}{c}234.0 \\
\pm 11.70^{\mathrm{b}}\end{array}$ & $\begin{array}{c}242.0 \\
\pm 12.10^{\mathrm{b}}\end{array}$ & $\begin{array}{c}235.6 \\
\pm 11.78^{b}\end{array}$ & $\begin{array}{c}221.0 \\
\pm 11.05^{\mathrm{b}}\end{array}$ & $\begin{array}{c}291.7 \\
\pm 14.59^{\mathrm{a}}\end{array}$ & $\begin{array}{c}297.8 \\
\pm 14.89^{\mathrm{a}}\end{array}$ & $\begin{array}{c}302.2 \\
\pm 15.11^{\mathrm{a}}\end{array}$ & $\begin{array}{c}312.8 \\
\pm 15.64^{\mathrm{a}}\end{array}$ \\
\hline$\alpha$-Linolenic (C18:3n3) & $\begin{array}{c}186.0 \\
\pm 9.30^{\mathrm{d}}\end{array}$ & $\begin{array}{c}295.9 \\
\pm 14.80^{\mathrm{a}}\end{array}$ & $\begin{array}{c}278.1 \\
\pm 13.91^{\mathrm{b}}\end{array}$ & $\begin{array}{c}257.8 \\
\pm 12.89^{c}\end{array}$ & $\begin{array}{l}20.1 \\
\pm 1.0^{\mathrm{e}}\end{array}$ & $\begin{array}{c}20.9 \\
\pm 1.05^{\mathrm{e}}\end{array}$ & $\begin{array}{c}23.9 \\
\pm 1.20^{\mathrm{e}}\end{array}$ & $\begin{array}{c}20.6 \\
\pm 1.03^{\mathrm{e}}\end{array}$ \\
\hline Ecosadienoic acid (C20:2) & ND & ND & ND & ND & $\begin{array}{c}4.6 \\
\pm 0.23^{\mathrm{a}}\end{array}$ & 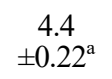 & $\begin{array}{c}5.5 \\
\pm 0.28^{\mathrm{a}}\end{array}$ & $\begin{array}{c}4.7 \\
\pm 0.24^{\mathrm{a}}\end{array}$ \\
\hline Arachidonic acid (C20:4n6) & ND & ND & ND & ND & $\begin{array}{c}3.8 \\
\pm 0.19^{\mathrm{b}}\end{array}$ & $\begin{array}{c}3.8 \\
\pm 0.19^{\mathrm{b}}\end{array}$ & $\begin{array}{c}4.9 \\
\pm 0.25^{\mathrm{a}}\end{array}$ & ND \\
\hline Nervonic acid (C24:1n9) & ND & ND & ND & ND & $\begin{array}{c}6.0 \\
\pm 0.30^{\mathrm{c}}\end{array}$ & $\begin{array}{c}8.0 \\
\pm 0.40^{\mathrm{b}}\end{array}$ & $\begin{array}{c}15.0 \\
\pm 0.75^{\mathrm{a}}\end{array}$ & $\begin{array}{c}10.7 \\
\pm 0.54^{\mathrm{ab}}\end{array}$ \\
\hline $\begin{array}{l}\text { Docosahexaenoic acid } \\
(\mathrm{C} 22: 6 \mathrm{n} 3)\end{array}$ & $\begin{array}{l}7.2 \\
\pm 0.36^{\mathrm{b}}\end{array}$ & $\begin{array}{c}5.6 \\
\pm 0.28^{\mathrm{ab}}\end{array}$ & $\begin{aligned} & 4.9 \\
\pm & 0.25^{\mathrm{ab}}\end{aligned}$ & $\begin{array}{l}3.0 \\
\pm 0.15^{\mathrm{c}}\end{array}$ & $\begin{array}{c}5.3 \\
\pm 0.27^{\mathrm{ab}}\end{array}$ & $\begin{array}{l}4.5 \\
\pm 0.23^{\mathrm{b}}\end{array}$ & $\begin{aligned} & 8.8 \\
\pm & 0.44^{\mathrm{a}}\end{aligned}$ & $\begin{array}{l}8.1 \\
\pm 0.41^{\mathrm{a}}\end{array}$ \\
\hline Total & 519.4 & 596.0 & 579.1 & 541.8 & 366.2 & 378.5 & 399.8 & 393.8 \\
\hline Total fatty acids & 888.4 & 948.3 & 884.6 & 837.5 & 663.7 & 668.1 & 691.7 & 659.9 \\
\hline
\end{tabular}

${ }^{1)}$ All values are presented as the mean \pm SD of triplicate determinations. All values within a column with different superscript letters represent statistically significant difference from each other at $\mathrm{p}<0.05$ by Duncan's multiple range test.

${ }^{2)} \mathrm{ND}$, not detected.

필수 아미노산의 경우, 볶음 처리 시간이 증가할수록 함량이 감소하는 것을 보였다. 또한 threonine, valine, isoleucine 및 lysine 등의 모든 필수 아미노산이 함량은 볶음 시간이 길어 질수록 함량이 감소하였다.

Kim 등(2019)은 열처리나 증숙 과정 중에 amino carbonyl
반응 중 갈변 반응에 의해 유리아미노산의 함량이 크게 감소 한다고 보고하였다. 또한 Van Voekel(2006)은 arginine과 lysine이 amino carbonyl 반응에 가장 먼저 관여하며, 이후 나머지 아미노산들이 반응하여 결국 아미노산의 함량이 크게 감소한다고 보고하여 이는 본 연구와 동일하였다. 
Table 3. Comprehensive changes of free amino acid contents of ginseng sprouts (above and below ground) according to the roasting process

\begin{tabular}{|c|c|c|c|c|c|c|c|c|}
\hline \multirow{2}{*}{ Contents (mg/100 g) } & \multicolumn{4}{|c|}{ Above ground / Roasting time $\left(\min , 150^{\circ} \mathrm{C}\right)$} & \multicolumn{4}{|c|}{ Below ground / Roasting time $\left(\mathrm{min}, 200^{\circ} \mathrm{C}\right)$} \\
\hline & 0 & 5 & 10 & 15 & 0 & 5 & 10 & 15 \\
\hline \multicolumn{9}{|l|}{ Non-essential amino acids } \\
\hline Phosphoetanolamine & $\mathrm{ND}^{1)}$ & ND & $\begin{array}{l}109.64 \\
\pm 5.48^{\mathrm{a}}\end{array}$ & $\begin{array}{l}89.08 \\
\pm 4.45^{\mathrm{b}}\end{array}$ & $\begin{array}{l}40.94 \\
\pm 2.05^{\mathrm{c}}\end{array}$ & $\begin{array}{l}47.30 \\
\pm 2.37^{\mathrm{c}}\end{array}$ & $\begin{array}{l}40.09 \\
\pm 2.00^{\mathrm{c}}\end{array}$ & $\begin{array}{l}47.97 \\
\pm 2.40^{\mathrm{c}}\end{array}$ \\
\hline Proline & $\begin{array}{c}40.96 \\
\pm 2.05^{\mathrm{b} 2)}\end{array}$ & $\begin{array}{l}13.37 \\
\pm 0.67^{\mathrm{c}}\end{array}$ & $\begin{array}{l}12.04 \\
\pm 0.60^{\mathrm{c}}\end{array}$ & $\begin{array}{c}9.61 \\
\pm 0.48^{\mathrm{cd}}\end{array}$ & $\begin{array}{l}96.89 \\
\pm 4.84^{\mathrm{a}}\end{array}$ & $\begin{array}{c}9.16 \\
\pm 0.46^{\mathrm{cd}}\end{array}$ & $\begin{array}{c}7.35 \\
\pm 0.37^{\mathrm{d}}\end{array}$ & $\begin{array}{c}8.14 \\
\pm 0.41^{\mathrm{cd}}\end{array}$ \\
\hline Hydroxyproline & $\begin{array}{c}0.78 \\
\pm 0.04^{\mathrm{b}}\end{array}$ & ND & ND & ND & $\begin{array}{c}1.04 \\
\pm 0.05^{\mathrm{a}}\end{array}$ & ND & ND & ND \\
\hline Aspartic acid & $\begin{array}{l}131.25 \\
\pm 6.56^{\mathrm{bc}}\end{array}$ & $\begin{array}{l}162.26 \\
\pm 8.11^{\mathrm{a}}\end{array}$ & $\begin{array}{l}143.86 \\
\pm 7.19^{\mathrm{b}}\end{array}$ & $\begin{array}{l}119.34 \\
\pm 5.97^{\mathrm{c}}\end{array}$ & $\begin{array}{l}89.29 \\
\pm 4.46^{\mathrm{d}}\end{array}$ & $\begin{array}{l}147.15 \\
\pm 7.36^{\mathrm{b}}\end{array}$ & $\begin{array}{l}122.22 \\
\pm 6.11^{\mathrm{c}}\end{array}$ & $\begin{array}{l}136.69 \\
\pm 6.83^{\mathrm{bc}}\end{array}$ \\
\hline Serine & $\begin{array}{l}88.74 \\
\pm 4.44^{\mathrm{a}}\end{array}$ & $\begin{array}{l}58.17 \\
\pm 2.91^{\mathrm{b}}\end{array}$ & $\begin{array}{l}52.69 \\
\pm 2.63^{\mathrm{b}}\end{array}$ & $\begin{array}{c}43.01 \\
\pm 2.15^{\mathrm{bc}}\end{array}$ & $\begin{array}{l}49.38 \\
\pm 2.47^{\mathrm{b}}\end{array}$ & $\begin{array}{l}35.86 \\
\pm 1.79^{c}\end{array}$ & $\begin{array}{l}29.39 \\
\pm 1.47^{\mathrm{c}}\end{array}$ & $\begin{array}{l}32.96 \\
\pm 1.65^{\mathrm{c}}\end{array}$ \\
\hline Aspartic acid - $\mathrm{NH}_{2}$ & $\begin{array}{l}187.59 \\
\pm 9.38^{\mathrm{a}}\end{array}$ & $\begin{array}{l}118.71 \\
\pm 5.94^{\mathrm{b}}\end{array}$ & $\begin{array}{l}101.91 \\
\pm 5.10^{\text {bc }}\end{array}$ & $\begin{array}{l}82.22 \\
\pm 4.11^{\mathrm{c}}\end{array}$ & $\begin{array}{l}174.17 \\
\pm 8.71^{\mathrm{a}}\end{array}$ & $\begin{array}{l}122.86 \\
\pm 6.14^{\mathrm{b}}\end{array}$ & $\begin{array}{c}99.86 \\
\pm 4.99^{\mathrm{bc}}\end{array}$ & $\begin{array}{l}106.21 \\
\pm 5.31^{\text {bc }}\end{array}$ \\
\hline Glutamic acid & $\begin{array}{l}60.25 \\
\pm 3.01^{\mathrm{d}}\end{array}$ & $\begin{array}{l}107.55 \\
\pm 5.38^{\mathrm{b}}\end{array}$ & $\begin{array}{l}100.01 \\
\pm 5.00^{\mathrm{b}}\end{array}$ & $\begin{array}{l}84.47 \\
\pm 4.22^{\mathrm{c}}\end{array}$ & $\begin{array}{l}122.30 \\
\pm 6.12^{\mathrm{a}}\end{array}$ & $\begin{array}{l}133.35 \\
\pm 6.67^{\mathrm{a}}\end{array}$ & $\begin{array}{l}104.11 \\
\pm 5.21^{\mathrm{b}}\end{array}$ & $\begin{array}{l}109.68 \\
\pm 5.48^{\mathrm{b}}\end{array}$ \\
\hline Sarcosine & $\begin{array}{c}2.53 \\
\pm 0.13^{\mathrm{c}}\end{array}$ & $\begin{array}{c}3.10 \\
\pm 0.16^{\mathrm{b}}\end{array}$ & $\begin{array}{c}3.25 \\
\pm 0.16^{\mathrm{b}}\end{array}$ & $\begin{array}{c}3.23 \\
\pm 0.16^{\mathrm{b}}\end{array}$ & $\begin{array}{c}4.12 \\
\pm 0.21^{\mathrm{a}}\end{array}$ & $\begin{array}{c}4.01 \\
\pm 0.20^{\mathrm{a}}\end{array}$ & $\begin{array}{c}3.34 \\
\pm 0.17^{\mathrm{b}}\end{array}$ & $\begin{array}{c}4.29 \\
\pm 0.21^{\mathrm{a}}\end{array}$ \\
\hline Aminoadipic acid & $\begin{array}{c}6.46 \\
\pm 0.32^{\mathrm{a}}\end{array}$ & $\begin{aligned} & 4.06 \\
\pm & 0.20^{\mathrm{bc}}\end{aligned}$ & $\begin{array}{c}3.35 \\
\pm 0.17^{\mathrm{c}}\end{array}$ & $\begin{array}{c}2.74 \\
\pm 0.14^{\mathrm{c}}\end{array}$ & $\begin{array}{c}4.81 \\
\pm 0.24^{\mathrm{b}}\end{array}$ & $\begin{array}{c}1.39 \\
\pm 0.07^{\mathrm{d}}\end{array}$ & $\begin{array}{c}1.06 \\
\pm 0.05^{\mathrm{d}}\end{array}$ & $\begin{array}{l}1.22 \\
\pm 0.06^{\mathrm{d}}\end{array}$ \\
\hline Glycine & $\begin{array}{l}12.96 \\
\pm 0.65^{\mathrm{b}}\end{array}$ & $\begin{array}{c}4.93 \\
\pm 0.25^{\mathrm{cd}}\end{array}$ & $\begin{array}{c}4.85 \\
\pm 0.24^{\text {cd }}\end{array}$ & $\begin{array}{c}4.52 \\
\pm 0.23^{\mathrm{d}}\end{array}$ & $\begin{array}{l}15.21 \\
\pm 0.74^{\mathrm{a}}\end{array}$ & $\begin{array}{c}5.69 \\
\pm 0.28^{\mathrm{c}}\end{array}$ & $\begin{array}{c}5.12 \\
\pm 0.26^{\mathrm{cd}}\end{array}$ & $\begin{array}{c}5.85 \\
\pm 0.29^{\mathrm{c}}\end{array}$ \\
\hline Alanine & $\begin{array}{l}80.40 \\
\pm 4.02^{\mathrm{b}}\end{array}$ & $\begin{array}{l}40.29 \\
\pm 2.01^{\mathrm{c}}\end{array}$ & $\begin{array}{l}41.17 \\
\pm 2.06^{\mathrm{c}}\end{array}$ & $\begin{array}{c}33.09 \\
\pm 1.65^{\mathrm{cd}}\end{array}$ & $\begin{array}{l}106.76 \\
\pm 5.34^{\mathrm{a}}\end{array}$ & $\begin{array}{c}34.50 \\
\pm 1.73^{\text {cd }}\end{array}$ & $\begin{array}{l}28.44 \\
\pm 1.42^{\mathrm{d}}\end{array}$ & $\begin{array}{c}31.11 \\
\pm 1.56^{\mathrm{cd}}\end{array}$ \\
\hline Citrulline & ND & ND & ND & ND & $\begin{array}{c}15.59 \\
\pm 0.78^{b}\end{array}$ & $\begin{array}{c}2.82 \\
\pm 0.14^{\mathrm{c}}\end{array}$ & $\begin{array}{c}2.35 \\
\pm 0.12^{\mathrm{c}}\end{array}$ & $\begin{array}{c}3.68 \\
\pm 0.18^{\mathrm{a}}\end{array}$ \\
\hline$\alpha$-Aminobutyric acid & $\begin{array}{c}53.0 \\
\pm 2.65^{\mathrm{a}}\end{array}$ & $\begin{array}{l}22.21 \\
\pm 1.11^{\mathrm{b}}\end{array}$ & $\begin{array}{l}25.96 \\
\pm 1.30^{\mathrm{b}}\end{array}$ & $\begin{array}{l}21.07 \\
\pm 1.05^{\mathrm{b}}\end{array}$ & $\begin{array}{c}6.85 \\
\pm 0.34^{\mathrm{d}}\end{array}$ & $\begin{array}{l}10.50 \\
\pm 0.53^{\mathrm{c}}\end{array}$ & $\begin{array}{l}12.39 \\
\pm 2.97^{\mathrm{c}}\end{array}$ & $\begin{array}{l}20.76 \\
\pm 1.04^{\mathrm{b}}\end{array}$ \\
\hline Cystine & ND & $\begin{array}{l}32.16 \\
\pm 1.61^{\mathrm{b}}\end{array}$ & $\begin{array}{l}44.09 \\
\pm 2.20^{\mathrm{a}}\end{array}$ & ND & $\begin{array}{c}4.90 \\
\pm 0.25^{\mathrm{c}}\end{array}$ & ND & ND & ND \\
\hline Cystathionine & ND & ND & ND & ND & $\begin{array}{c}2.54 \\
\pm 0.13^{\mathrm{b}}\end{array}$ & $\begin{array}{c}2.91 \\
\pm 0.14^{\mathrm{b}}\end{array}$ & $\begin{array}{c}2.46 \\
\pm 0.12^{\mathrm{b}}\end{array}$ & $\begin{array}{c}6.44 \\
\pm 0.32^{\mathrm{a}}\end{array}$ \\
\hline Tyrosine & $\begin{array}{c}43.60 \\
\pm 2.18^{\mathrm{cd}}\end{array}$ & $\begin{array}{l}21.61 \\
\pm 1.08^{\mathrm{d}}\end{array}$ & $\begin{array}{l}20.10 \\
\pm 1.01^{\mathrm{d}}\end{array}$ & $\begin{array}{l}11.20 \\
\pm 0.56^{\mathrm{e}}\end{array}$ & $\begin{array}{l}116.81 \\
\pm 5.84^{\mathrm{a}}\end{array}$ & $\begin{array}{l}75.08 \\
\pm 0.53^{\mathrm{b}}\end{array}$ & $\begin{array}{l}59.48 \\
\pm 2.97^{c}\end{array}$ & $\begin{array}{l}75.31 \\
\pm 3.77^{\mathrm{b}}\end{array}$ \\
\hline$\beta$-Alanine & $\begin{array}{l}25.32 \\
\pm 1.27^{\mathrm{a}}\end{array}$ & $\begin{array}{c}19.22 \\
\pm 0.96^{\mathrm{ab}}\end{array}$ & $\begin{array}{c}20.32 \\
\pm 1.02^{\mathrm{ab}}\end{array}$ & $\begin{array}{c}8.51 \\
\pm 0.43^{\mathrm{c}}\end{array}$ & $\begin{array}{c}17.44 \\
\pm 0.87^{\mathrm{b}}\end{array}$ & $\begin{array}{c}18.28 \\
\pm 0.15^{\mathrm{b}}\end{array}$ & $\begin{array}{l}16.04 \\
\pm 0.80^{\mathrm{b}}\end{array}$ & $\begin{array}{c}22.64 \\
\pm 1.13^{\mathrm{ab}}\end{array}$ \\
\hline$\beta$-Aminoisobutyric acid & $\begin{array}{l}12.42 \\
\pm 0.62^{\mathrm{b}}\end{array}$ & $\begin{array}{c}9.02 \\
\pm 0.45^{\mathrm{bc}}\end{array}$ & $\begin{array}{c}8.23 \\
\pm 0.41^{\mathrm{c}}\end{array}$ & $\begin{array}{c}0.97 \\
\pm 0.05^{\mathrm{d}}\end{array}$ & $\begin{array}{l}16.58 \\
\pm 0.83^{\mathrm{a}}\end{array}$ & $\begin{array}{c}10.19 \\
\pm 3.75^{\mathrm{bc}}\end{array}$ & $\begin{array}{c}9.15 \\
\pm 0.46^{\mathrm{bc}}\end{array}$ & $\begin{array}{l}15.52 \\
\pm 0.78^{\mathrm{a}}\end{array}$ \\
\hline$\gamma$-Aminobutyric acid & $\begin{array}{l}120.70 \\
\pm 6.04^{\mathrm{c}}\end{array}$ & $\begin{array}{l}53.03 \\
\pm 2.65^{\mathrm{d}}\end{array}$ & $\begin{array}{l}53.54 \\
\pm 2.68^{\mathrm{d}}\end{array}$ & $\begin{array}{c}37.74 \\
\pm 1.89^{\mathrm{e}}\end{array}$ & $\begin{array}{l}151.18 \\
\pm 7.56^{\mathrm{b}}\end{array}$ & $\begin{array}{l}158.18 \\
\pm 7.91^{\mathrm{b}}\end{array}$ & $\begin{array}{l}137.31 \\
\pm 6.87^{\mathrm{c}}\end{array}$ & $\begin{array}{l}177.03 \\
\pm 8.85^{\mathrm{a}}\end{array}$ \\
\hline Aminoethanol & $\begin{array}{l}20.74 \\
\pm 1.04^{\mathrm{a}}\end{array}$ & $\begin{array}{c}7.51 \\
\pm 0.38^{\mathrm{bc}}\end{array}$ & $\begin{array}{c}7.58 \\
\pm 0.39^{\text {bc }}\end{array}$ & $\begin{array}{l}3.87 \\
\pm 0.19^{\mathrm{d}}\end{array}$ & $\begin{array}{l}20.43 \\
\pm 1.02^{\mathrm{a}}\end{array}$ & $\begin{array}{c}8.84 \\
\pm 0.44^{\mathrm{b}}\end{array}$ & $\begin{array}{c}6.14 \\
\pm 0.31^{\mathrm{c}}\end{array}$ & $\begin{array}{c}8.87 \\
\pm 0.44^{\mathrm{b}}\end{array}$ \\
\hline Hydroxylysine & $\begin{aligned} & 2.24 \\
\pm & 0.11^{\mathrm{ab}}\end{aligned}$ & $\begin{array}{c}1.88 \\
\pm 0.09^{b}\end{array}$ & $\begin{array}{c}1.76 \\
\pm 0.09^{\mathrm{c}}\end{array}$ & $\begin{array}{c}1.73 \\
\pm 0.09^{\mathrm{c}}\end{array}$ & $\begin{array}{c}2.69 \\
\pm 0.13^{\mathrm{a}}\end{array}$ & $\begin{array}{c}1.99 \\
\pm 0.10^{\mathrm{b}}\end{array}$ & $\begin{array}{c}1.90 \\
\pm 0.10^{\mathrm{b}}\end{array}$ & $\begin{array}{c}1.91 \\
\pm 0.10^{\mathrm{b}}\end{array}$ \\
\hline
\end{tabular}


(continued)

\begin{tabular}{|c|c|c|c|c|c|c|c|c|}
\hline \multirow{2}{*}{ Contents $(\mathrm{mg} / 100 \mathrm{~g})$} & \multicolumn{4}{|c|}{ Above ground / Roasting time $\left(\mathrm{min}, 150^{\circ} \mathrm{C}\right)$} & \multicolumn{4}{|c|}{ Below ground / Roasting time $\left(\min , 200^{\circ} \mathrm{C}\right)$} \\
\hline & 0 & 5 & 10 & 15 & 0 & 5 & 10 & 15 \\
\hline Ornithine & $\begin{array}{l}20.81 \\
\pm 1.04^{\mathrm{b}}\end{array}$ & $\begin{array}{c}18.28 \\
\pm 0.91^{\mathrm{c}}\end{array}$ & $\begin{array}{l}14.71 \\
\pm 0.74^{\mathrm{d}}\end{array}$ & $\begin{array}{l}12.92 \\
\pm 0.65\end{array}$ & $\begin{array}{l}52.99 \\
\pm 2.65^{\mathrm{a}}\end{array}$ & $\begin{array}{l}10.55 \\
\pm 0.53^{\mathrm{e}}\end{array}$ & $\begin{array}{c}8.56 \\
\pm 0.43^{\mathrm{f}}\end{array}$ & $\begin{array}{c}3.41 \\
\pm 0.17^{\mathrm{g}}\end{array}$ \\
\hline 1-Methylhistidine & ND & ND & ND & ND & $\begin{array}{c}1.40 \\
\pm 0.07^{\mathrm{b}}\end{array}$ & $\begin{array}{c}1.61 \\
\pm 0.08^{\mathrm{a}}\end{array}$ & $\begin{array}{c}1.34 \\
\pm 0.07^{\mathrm{c}}\end{array}$ & $\begin{aligned} & 1.58 \\
\pm & 0.08^{\mathrm{ab}}\end{aligned}$ \\
\hline 3-Methylhistidine & $\begin{array}{c}0.95 \\
\pm 0.05^{\mathrm{a}}\end{array}$ & $\begin{array}{c}0.53 \\
\pm 0.03^{\mathrm{d}}\end{array}$ & ND & ND & $\begin{array}{c}0.88 \\
\pm 0.04^{\mathrm{a}}\end{array}$ & $\begin{array}{c}0.56 \\
\pm 0.03^{\mathrm{d}}\end{array}$ & $\begin{array}{c}0.65 \\
\pm 0.03^{\mathrm{b}}\end{array}$ & $\begin{aligned} & 0.77 \\
\pm & 0.04^{\mathrm{bc}}\end{aligned}$ \\
\hline Arginine & $\begin{array}{l}234.36 \\
\pm 11.72^{\mathrm{d}}\end{array}$ & $\begin{array}{l}192.15 \\
\pm 9.61^{\mathrm{e}}\end{array}$ & $\begin{array}{l}144.41 \\
\pm 7.22^{\mathrm{f}}\end{array}$ & $\begin{array}{l}118.32 \\
\pm 5.92^{\mathrm{g}}\end{array}$ & $\begin{array}{c}2,970.83 \\
\pm 18.54^{\mathrm{a}}\end{array}$ & $\begin{array}{l}3,021.35 \\
\pm 11.07^{\mathrm{a}}\end{array}$ & $\begin{array}{l}2,461.01 \\
\pm 13.05^{\mathrm{c}}\end{array}$ & $\begin{array}{c}2,648.84 \\
\pm 12.44^{\mathrm{b}}\end{array}$ \\
\hline Total & $1,146.06$ & 890.04 & 913.47 & 687.64 & $4,086.02$ & $3,864.13$ & $3,159.76$ & $3,470.88$ \\
\hline \multicolumn{9}{|l|}{ Essential amino acids } \\
\hline Threonine & $\begin{array}{l}49.18 \\
\pm 2.46^{\mathrm{a}}\end{array}$ & $\begin{array}{c}28.72 \\
\pm 1.44^{\mathrm{ab}}\end{array}$ & $\begin{array}{c}27.10 \\
\pm 1.36^{\mathrm{ab}}\end{array}$ & $\begin{array}{c}22.39 \\
\pm 1.12^{\mathrm{b}}\end{array}$ & $\begin{array}{l}54.18 \\
\pm 2.71^{\mathrm{a}}\end{array}$ & $\begin{array}{c}34.07 \\
\pm 1.70^{\mathrm{ab}}\end{array}$ & $\begin{array}{c}27.40 \\
\pm 1.37^{\mathrm{ab}}\end{array}$ & $\begin{array}{c}29.72 \\
\pm 1.49^{\mathrm{ab}}\end{array}$ \\
\hline Valine & $\begin{array}{l}80.48 \\
\pm 4.02^{\mathrm{a}}\end{array}$ & $\begin{array}{l}29.14 \\
\pm 1.46^{\mathrm{c}}\end{array}$ & $\begin{array}{l}44.09 \\
\pm 2.20^{\mathrm{b}}\end{array}$ & $\begin{array}{l}34.85 \\
\pm 1.74^{\mathrm{c}}\end{array}$ & $\begin{array}{l}76.56 \\
\pm 3.83^{\mathrm{a}}\end{array}$ & $\begin{array}{l}47.57 \\
\pm 2.38^{\mathrm{b}}\end{array}$ & $\begin{array}{l}39.06 \\
\pm 1.95^{\mathrm{b}}\end{array}$ & $\begin{array}{l}46.00 \\
\pm 2.30^{\mathrm{b}}\end{array}$ \\
\hline Methionine & $\begin{array}{l}20.29 \\
\pm 1.01^{\mathrm{a}}\end{array}$ & $\begin{array}{c}2.50 \\
\pm 0.13^{\mathrm{d}}\end{array}$ & ND & ND & $\begin{array}{l}20.12 \\
\pm 1.01^{\mathrm{a}}\end{array}$ & $\begin{array}{c}16.19 \\
\pm 0.81^{\mathrm{b}}\end{array}$ & $\begin{array}{l}12.19 \\
\pm 0.61^{\mathrm{c}}\end{array}$ & $\begin{array}{c}19.53 \\
\pm 0.98^{\mathrm{a}}\end{array}$ \\
\hline Isoleucine & $\begin{array}{c}54.90 \\
\pm 2.75^{\text {ab }}\end{array}$ & $\begin{array}{l}49.11 \\
\pm 2.46^{\mathrm{b}}\end{array}$ & $\begin{array}{l}58.47 \\
\pm 2.92^{\mathrm{a}}\end{array}$ & $\begin{array}{l}47.63 \\
\pm 2.38^{b}\end{array}$ & $\begin{array}{r}66.40 \\
\pm 3.32^{\mathrm{a}}\end{array}$ & $\begin{array}{l}46.73 \\
\pm 2.34^{\mathrm{b}}\end{array}$ & $\begin{array}{l}37.63 \\
\pm 1.88^{c}\end{array}$ & $\begin{array}{l}48.13 \\
\pm 2.41^{\mathrm{b}}\end{array}$ \\
\hline Leucine & $\begin{array}{l}55.36 \\
\pm 2.77^{\mathrm{b}}\end{array}$ & $\begin{array}{l}21.38 \\
\pm 1.07^{\mathrm{e}}\end{array}$ & $\begin{array}{l}18.57 \\
\pm 0.93^{\mathrm{e}}\end{array}$ & $\begin{array}{l}12.49 \\
\pm 0.62^{\mathrm{f}}\end{array}$ & $\begin{array}{l}94.85 \\
\pm 4.74^{\mathrm{a}}\end{array}$ & $\begin{array}{c}47.08 \\
\pm 2.35^{\mathrm{bc}}\end{array}$ & $\begin{array}{l}36.47 \\
\pm 1.82^{\mathrm{d}}\end{array}$ & $\begin{array}{l}43.15 \\
\pm 0.16^{\mathrm{c}}\end{array}$ \\
\hline Phenylalanine & $\begin{array}{l}47.57 \\
\pm 2.38^{\mathrm{c}}\end{array}$ & $\begin{array}{l}23.30 \\
\pm 1.17^{\mathrm{d}}\end{array}$ & $\begin{array}{l}20.73 \\
\pm 1.04^{\mathrm{d}}\end{array}$ & $\begin{array}{c}8.75 \\
\pm 0.44^{\mathrm{e}}\end{array}$ & $\begin{array}{l}99.94 \\
\pm 5.00^{\mathrm{a}}\end{array}$ & $\begin{array}{c}69.50 \\
\pm 3.48^{\mathrm{b}}\end{array}$ & $\begin{array}{l}54.29 \\
\pm 2.71^{\mathrm{c}}\end{array}$ & $\begin{array}{c}68.98 \\
\pm 3.45^{\mathrm{b}}\end{array}$ \\
\hline Lysine & $\begin{array}{l}55.31 \\
\pm 2.77^{\mathrm{c}}\end{array}$ & $\begin{array}{c}17.16 \\
\pm 0.86^{\mathrm{d}}\end{array}$ & $\begin{array}{l}11.15 \\
\pm 0.56^{\mathrm{e}}\end{array}$ & $\begin{array}{c}9.11 \\
\pm 0.46^{\mathrm{f}}\end{array}$ & $\begin{array}{l}133.02 \\
\pm 6.65^{\mathrm{a}}\end{array}$ & $\begin{array}{l}81.08 \\
\pm 4.05^{\mathrm{b}}\end{array}$ & $\begin{array}{r}64.17 \\
\pm 3.21^{\mathrm{c}}\end{array}$ & $\begin{array}{l}66.66 \\
\pm 3.33^{c}\end{array}$ \\
\hline Histidine & $\begin{array}{c}19.93 \\
\pm 1.00^{\mathrm{d}}\end{array}$ & $\begin{array}{c}10.64 \\
\pm 0.53^{\mathrm{e}}\end{array}$ & $\begin{array}{c}8.31 \\
\pm 0.42^{\text {f }}\end{array}$ & $\begin{array}{c}6.53 \\
\pm 0.33^{\mathrm{g}}\end{array}$ & $\begin{array}{l}87.28 \\
\pm 4.36^{\mathrm{a}}\end{array}$ & $\begin{array}{l}59.32 \\
\pm 2.97^{\mathrm{b}}\end{array}$ & $\begin{array}{l}45.71 \\
\pm 2.29^{c}\end{array}$ & $\begin{array}{l}47.72 \\
\pm 2.39^{c}\end{array}$ \\
\hline Total & 383.02 & 181.95 & 188.42 & 141.75 & 632.35 & 401.54 & 316.92 & 369.89 \\
\hline Total amino acids & $1,529.08$ & $1,071.99$ & $1,101.89$ & 829.39 & $4,718.37$ & $4,265.67$ & $3,476.68$ & $3,840.77$ \\
\hline
\end{tabular}

${ }^{1)} \mathrm{ND}$, not detected.

${ }^{2)}$ All values are presented as the mean $\pm \mathrm{SD}$ of triplicate determinations. All values within a column with different superscript letters represent statistically significant difference from each other at $\mathrm{p}<0.05$ by Duncan's multiple range test.

\section{볶음 처리에 따른 새싹인삼의 무기질 변화}

새싹인삼의 볶음 처리에 따른 지상부 및 지하부 무기질 함 량 비교는 Table 4와 같았다. 지상부 및 지하부 모두 칼륨의 함량이 가장 높았다. 지상부의 칼륨 함량은 0 분, 5 분, 10 분 및 15 분 볶음 처리를 하였을 때 $34.67 \mathrm{mg} / 100 \mathrm{~g}, 34.85$ $\mathrm{mg} / 100 \mathrm{~g}, 33.14 \mathrm{mg} / 100 \mathrm{~g}$ 및 $34.11 \mathrm{mg} / 100 \mathrm{~g}$ 으로 큰 차이 를 보이지 않았다. 지하부 역시 $23.06 \mathrm{mg} / 100 \mathrm{~g}, 22.96$ $\mathrm{mg} / 100 \mathrm{~g}, 21.32 \mathrm{mg} / 100 \mathrm{~g}$ 및 $23.59 \mathrm{mg} / 100 \mathrm{~g}$ 으로 볶음 처 리에 따른 큰 차이를 보이지 않았다. 인의 함량이 두 번째로 가장 높았으며, 지상부의 경우 0 분 및 15 분 붂음 처리시 4.20 $\mathrm{mg} / 100 \mathrm{~g}$ 및 $3.61 \mathrm{mg} / 100 \mathrm{~g}$ 으로 15 분 볶음 처리 시 가장 낮
은 함량을 보였다. 지하부의 경우에도 인이 두 번째로 높은 함량을 나타냈으며, 0 분 및 15 분 볶음 처리하였을 때 4.26 $\mathrm{mg} / 100 \mathrm{~g}$ 및 $4.97 \mathrm{mg} / 100 \mathrm{~g}$ 으로 큰 차이를 보이지 않았다. 구리, 아연 및 망간은 미량 검출되었으며, 나트륨 또한 평균 $2.57 \mathrm{mg} / 100 \mathrm{~g}$ 의 함량으로 시료에 열처리를 하여도 무기질 의 함량에는 유의적인 차이를 보이지 않았다.

\section{볶음 처리에 따른 새싹인삼의 총 phenolics, flavonoids 함량 및 갈변물질 변화}

새싹인삼의 볶음 처리에 따른 총 phenolics, 총 flavonoids 및 갈변물질 함량은 Fig. 2 와 같았다. 지상부의 총 phenolics 
Table 4. Comprehensive changes of mineral contents of ginseng sprouts (above and below ground) according to the roasting process

\begin{tabular}{|c|c|c|c|c|c|c|c|c|}
\hline \multirow{2}{*}{ Contents $(\mathrm{mg} / 100 \mathrm{~g})$} & \multicolumn{4}{|c|}{ Above ground / Roasting time $\left(\min , 150^{\circ} \mathrm{C}\right)$} & \multicolumn{4}{|c|}{ Below ground / Roasting time $\left(\min , 200^{\circ} \mathrm{C}\right)$} \\
\hline & 0 & 5 & 10 & 15 & 0 & 5 & 10 & 15 \\
\hline Phosphorus (P) & $\begin{array}{c}4.20 \\
\pm 0.21^{\mathrm{b} 1)}\end{array}$ & $\begin{array}{c}4.14 \\
\pm 0.21^{\mathrm{b}}\end{array}$ & $\begin{array}{c}3.80 \\
\pm 0.19^{\mathrm{c}}\end{array}$ & $\begin{array}{c}3.61 \\
\pm 0.18^{\mathrm{c}}\end{array}$ & $\begin{array}{c}4.26 \\
\pm 0.21^{\mathrm{b}}\end{array}$ & $\begin{array}{c}4.26 \\
\pm 0.21^{\mathrm{b}}\end{array}$ & $\begin{array}{c}4.24 \\
\pm 0.21^{\mathrm{b}}\end{array}$ & $\begin{array}{c}4.97 \\
\pm 0.25^{\mathrm{a}}\end{array}$ \\
\hline Sulfur (S) & $\begin{array}{c}2.56 \\
\pm 0.13^{\mathrm{d}}\end{array}$ & $\begin{array}{c}2.84 \\
\pm 0.14^{\mathrm{d}}\end{array}$ & $\begin{array}{l}2.52 \\
\pm 0.1^{\mathrm{d}}\end{array}$ & $\begin{array}{c}2.73 \\
\pm 0.14^{\mathrm{d}}\end{array}$ & $\begin{array}{c}3.21 \\
\pm 0.16^{\mathrm{c}}\end{array}$ & $\begin{array}{c}3.69 \\
\pm 0.18^{\mathrm{a}}\end{array}$ & $\begin{array}{c}3.66 \\
\pm 0.18^{\mathrm{a}}\end{array}$ & $\begin{array}{c}4.18 \\
\pm 0.21^{\mathrm{b}}\end{array}$ \\
\hline Kalium (K) & $\begin{array}{l}34.67 \\
\pm 1.73^{\mathrm{a}}\end{array}$ & $\begin{array}{l}34.85 \\
\pm 1.74^{\mathrm{a}}\end{array}$ & $\begin{array}{l}33.14 \\
\pm 1.66^{\mathrm{a}}\end{array}$ & $\begin{array}{l}34.11 \\
\pm 1.71^{\mathrm{a}}\end{array}$ & $\begin{array}{l}23.06 \\
\pm 1.15^{\mathrm{b}}\end{array}$ & $\begin{array}{l}22.96 \\
\pm 1.15^{\mathrm{b}}\end{array}$ & $\begin{array}{l}21.32 \\
\pm 1.07^{\mathrm{b}}\end{array}$ & $\begin{array}{l}23.59 \\
\pm 1.18^{\mathrm{b}}\end{array}$ \\
\hline Calcium $(\mathrm{Ca})$ & $\begin{array}{c}2.86 \\
\pm 0.14^{\mathrm{d}}\end{array}$ & $\begin{array}{l}3.06 \\
\pm 0.15^{\mathrm{cd}}\end{array}$ & $\begin{array}{c}3.36 \\
\pm 0.17^{\mathrm{c}}\end{array}$ & $\begin{array}{c}3.82 \\
\pm 0.19^{\mathrm{b}}\end{array}$ & $\begin{array}{c}3.42 \\
\pm 0.17^{\mathrm{c}}\end{array}$ & $\begin{array}{c}3.89 \\
\pm 0.19^{\mathrm{b}}\end{array}$ & $\begin{array}{c}3.94 \\
\pm 0.20^{\mathrm{b}}\end{array}$ & $\begin{array}{c}4.28 \\
\pm 0.21^{\mathrm{a}}\end{array}$ \\
\hline Magnesium (Mg) & $\begin{array}{c}1.71 \\
\pm 0.09^{\mathrm{b}}\end{array}$ & $\begin{array}{c}1.69 \\
\pm 0.08^{\mathrm{b}}\end{array}$ & $\begin{array}{c}1.58 \\
\pm 0.08^{\mathrm{bc}}\end{array}$ & $\begin{array}{c}1.42 \\
\pm 0.07^{\mathrm{c}}\end{array}$ & $\begin{array}{c}2.76 \\
\pm 0.14^{\mathrm{a}}\end{array}$ & $\begin{array}{c}2.81 \\
\pm 0.14^{\mathrm{a}}\end{array}$ & $\begin{array}{c}2.69 \\
\pm 0.13^{\mathrm{a}}\end{array}$ & $\begin{array}{c}2.89 \\
\pm 0.14^{\mathrm{a}}\end{array}$ \\
\hline Iron $(\mathrm{Fe})$ & $\begin{array}{c}0.06 \\
\pm 0.00^{\mathrm{b}}\end{array}$ & $\begin{array}{c}0.07 \\
\pm 0.00^{\mathrm{b}}\end{array}$ & $\begin{array}{c}0.07 \\
\pm 0.00^{\mathrm{b}}\end{array}$ & $\begin{array}{c}0.07 \\
\pm 0.00^{\mathrm{b}}\end{array}$ & $\begin{array}{c}0.11 \\
\pm 0.01^{\mathrm{a}}\end{array}$ & $\begin{array}{c}0.10 \\
\pm 0.01^{\mathrm{a}}\end{array}$ & $\begin{array}{c}0.10 \\
\pm 0.01^{\mathrm{a}}\end{array}$ & $\begin{array}{c}0.10 \\
\pm 0.01^{\mathrm{a}}\end{array}$ \\
\hline Copper $(\mathrm{Cu})$ & $\begin{array}{c}0.02 \\
\pm 0.00^{\mathrm{a}}\end{array}$ & $\begin{array}{c}0.02 \\
\pm 0.00^{\mathrm{a}}\end{array}$ & $\begin{array}{c}0.02 \\
\pm 0.00^{\mathrm{a}}\end{array}$ & $\begin{array}{c}0.02 \\
\pm 0.00^{\mathrm{a}}\end{array}$ & $\begin{array}{c}0.01 \\
\pm 0.00^{\mathrm{a}}\end{array}$ & $\begin{array}{c}0.01 \\
\pm 0.00^{\mathrm{a}}\end{array}$ & $\begin{array}{c}0.01 \\
\pm 0.00^{\mathrm{a}}\end{array}$ & $\begin{array}{c}0.02 \\
\pm 0.00^{\mathrm{a}}\end{array}$ \\
\hline Zinc $(\mathrm{Zn})$ & $\begin{array}{c}0.03 \\
\pm 0.00^{\mathrm{a}}\end{array}$ & $\begin{array}{c}0.03 \\
\pm 0.00^{\mathrm{a}}\end{array}$ & $\begin{array}{c}0.03 \\
\pm 0.00^{\mathrm{a}}\end{array}$ & $\begin{array}{c}0.03 \\
\pm 0.00^{\mathrm{a}}\end{array}$ & $\begin{array}{c}0.02 \\
\pm 0.00^{\mathrm{a}}\end{array}$ & $\begin{array}{c}0.02 \\
\pm 0.00^{\mathrm{a}}\end{array}$ & $\begin{array}{c}0.02 \\
\pm 0.00^{\mathrm{a}}\end{array}$ & $\begin{array}{c}0.02 \\
\pm 0.00^{\mathrm{a}}\end{array}$ \\
\hline Manganese (Mn) & $\begin{array}{c}0.03 \\
\pm 0.00^{\mathrm{a}}\end{array}$ & $\begin{array}{c}0.03 \\
\pm 0.00^{\mathrm{a}}\end{array}$ & $\begin{array}{c}0.03 \\
\pm 0.00^{\mathrm{a}}\end{array}$ & $\begin{array}{c}0.03 \\
\pm 0.00^{\mathrm{a}}\end{array}$ & $\begin{array}{c}0.02 \\
\pm 0.00^{\mathrm{a}}\end{array}$ & $\begin{array}{c}0.02 \\
\pm 0.00^{\mathrm{a}}\end{array}$ & $\begin{array}{c}0.02 \\
\pm 0.00^{\mathrm{a}}\end{array}$ & $\begin{array}{c}0.02 \\
\pm 0.00^{\mathrm{a}}\end{array}$ \\
\hline Sodium $(\mathrm{Na})$ & $\begin{array}{c}1.78 \\
\pm 0.09^{b}\end{array}$ & $\begin{array}{c}1.60 \\
\pm 0.08^{\mathrm{b}}\end{array}$ & $\begin{array}{c}1.66 \\
\pm 0.08^{\mathrm{b}}\end{array}$ & $\begin{array}{c}1.63 \\
\pm 0.08^{\mathrm{b}}\end{array}$ & $\begin{array}{c}2.61 \\
\pm 0.13^{\mathrm{a}}\end{array}$ & $\begin{array}{c}2.61 \\
\pm 0.13^{\mathrm{a}}\end{array}$ & $\begin{array}{l}2.37 \\
\pm 0.12^{\mathrm{a}}\end{array}$ & $\begin{array}{c}2.67 \\
\pm 0.13^{\mathrm{a}}\end{array}$ \\
\hline Aluminium $(\mathrm{Al})$ & $\begin{array}{c}0.12 \\
\pm 0.01^{\mathrm{b}}\end{array}$ & $\begin{array}{c}0.12 \\
\pm 0.01^{\mathrm{b}}\end{array}$ & $\begin{array}{c}0.11 \\
\pm 0.01^{\mathrm{b}}\end{array}$ & $\begin{array}{c}0.10 \\
\pm 0.01^{\mathrm{b}}\end{array}$ & $\begin{array}{c}0.22 \\
\pm 0.01^{\mathrm{a}}\end{array}$ & $\begin{array}{c}0.23 \\
\pm 0.01^{\mathrm{a}}\end{array}$ & $\begin{array}{c}0.23 \\
\pm 0.01^{\mathrm{a}}\end{array}$ & $\begin{array}{c}0.21 \\
\pm 0.01^{\mathrm{a}}\end{array}$ \\
\hline Silicon $(\mathrm{Si})$ & $\begin{array}{c}0.56 \\
\pm 0.03^{\mathrm{a}}\end{array}$ & $\begin{array}{c}0.57 \\
\pm 0.03^{\mathrm{a}}\end{array}$ & $\begin{array}{c}0.54 \\
\pm 0.03^{\mathrm{a}}\end{array}$ & $\begin{array}{c}0.56 \\
\pm 0.03^{\mathrm{a}}\end{array}$ & $\begin{array}{c}0.36 \\
\pm 0.02^{\mathrm{c}}\end{array}$ & $\begin{array}{c}0.48 \\
\pm 0.02^{\mathrm{ab}}\end{array}$ & $\begin{array}{c}0.40 \\
\pm 0.02^{\mathrm{b}}\end{array}$ & $\begin{array}{c}0.43 \\
\pm 0.02^{\mathrm{b}}\end{array}$ \\
\hline Total & 48.60 & 49.02 & 46.86 & 48.13 & 40.06 & 41.08 & 39.00 & 43.38 \\
\hline
\end{tabular}

${ }^{1)}$ All values are presented as the mean $\pm \mathrm{SD}$ of triplicate determination. All values within a column with different superscript letters represent statistically significant difference from each other at $\mathrm{p}<0.05$ by Duncan's multiple range test.

함량은 볶음 시간이 증가할수록 함량이 증가하였으며 원료일 때 $5.71 \mathrm{GAE} / \mathrm{g}$ 에서 15 분 볶음 처리 시 $7.84 \mathrm{GAE} / \mathrm{g}$ 으로 나 타났다. 지하부 역시 시간이 증가할수록 함량이 증가하였으 며, 각 볶음시간 별로 $1.37 \mathrm{GAE} / \mathrm{g}, 2.47 \mathrm{GAE} / \mathrm{g}, 3.13 \mathrm{GAE} / \mathrm{g}$ 및 $3.57 \mathrm{GAE} / \mathrm{g}$ 으로 나타났다(Fig. 2A). 총 flavonoids 함량은 Fig. $2 \mathrm{~B}$ 와 같았으며, 지상부 및 지하부 모두 볶음 시간이 증 가할수록 함량이 증가하였다. 지상부의 경우, 원료일 때 7.43 $\mathrm{RE} / \mathrm{g}$ 에서 5 분 볶음 처리하였을 때 $8.43 \mathrm{RE} / \mathrm{g}, 10$ 분 볶았을 때 $9.80 \mathrm{RE} / \mathrm{g}$ 및 15 분 볶았을 때 $9.95 \mathrm{RE} / \mathrm{g}$ 으로 증가하였으 며, 지하부 또한 원료일 때 $1.49 \mathrm{RE} / \mathrm{g}$ 에서 15 분 볶음 처리 시 $4.36 \mathrm{RE} / \mathrm{g}$ 으로 함량이 증가하였다. 지상부의 갈변물질은 원 료일 때 $2.635 \mathrm{OD} 420 \mathrm{~nm}$ 에서 15 분 볶음 처리 시 $3.022 \mathrm{OD} 420 \mathrm{~nm}$ 로 큰 차이를 보이지 않았으며, 지하부의 경우 $2.316 \mathrm{OD} 420 \mathrm{~nm}$ 에서 $2.987 \mathrm{OD} 420 \mathrm{~nm}$ 로 유의적 차이를 보이진 않았다(Fig. 2C).

Lee 등(2013)은 결명자의 볶음 처리에 따른 총 phenolics
함량을 비교하였다. $175^{\circ} \mathrm{C}$ 와 $200^{\circ} \mathrm{C}$ 에 원료일 때 $7.15 \mathrm{mg}$ $\mathrm{TAE} / \mathrm{g}$ 의 함량을 보였으나, 5 분 볶음 처리하였을 때 각각 $10.95 \mathrm{mg} \mathrm{TAE} / \mathrm{g}$ 및 $11.45 \mathrm{mg} \mathrm{TAE} / \mathrm{g}$ 으로 증가하였으며, 10 분 볶음 처리하였을 때 역시 $11.34 \mathrm{mg} \mathrm{TAE} / \mathrm{g}$ 및 $12.69 \mathrm{mg}$ $\mathrm{TAE} / \mathrm{g}$ 으로 함량이 증가하였다. 한편, 치커리(Hong 등, 1998), 감국(Kang 등, 2002) 등에서는 볶음처리 하였을 때 총 폴리 페놀의 함량이 증가된다고 보고하였다. Kwon 등(1997)은 둥 굴레의 볶음 처리에 따라 갈변반응이 증가한다고 보고하였 다. 이는 당 및 아미노산 등이 갈변반응이 진행시키는 요인이 되어 둥굴레의 볶음 처리의 결과와 유사하게 새싹인삼에서도 적용된 것으로 판단된다.

\section{볶음 처리에 따른 새싹인삼의 ginsenosides 함량 변화}

새싹인삼의 볶음 처리에 따른 ginsenoside 함량은 Table 5 및 Fig. 3 과 같았다. 지상부의 ginsenoside $\mathrm{Re}$ 의 경우, 볶음 

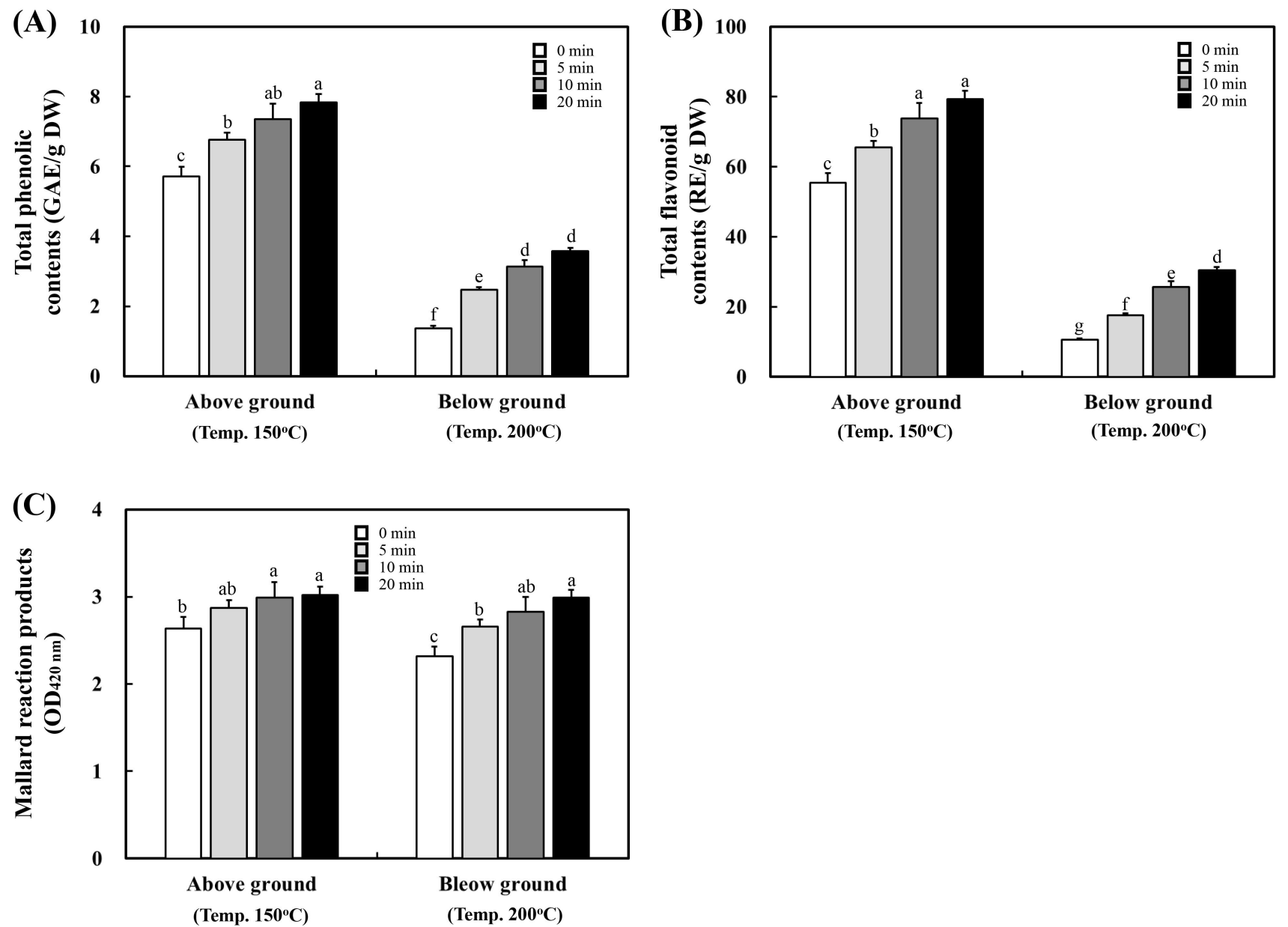

Fig. 2. Changes of total phenolics and total flavonoid contents and Maillard reaction products of ginseng sprouts according to the roasting process. (A), total phenolic contents; (B), total flavonoid contents; (C) Mallard reaction products.

All values are presented as the mean $\pm \mathrm{SD}$ of triplicate determinations. All values within a column with different superscript letters represent statistically significant difference from each other at $\mathrm{p}<0.05$ by Duncan's multiple range test.

시간이 증가할수록 $32.67 \mathrm{mg} / \mathrm{g}$ 에서 $21.02 \mathrm{mg} / \mathrm{g}, 19.97 \mathrm{mg} / \mathrm{g}$ 및 $19.40 \mathrm{mg} / \mathrm{g}$ 으로 함량이 감소하는 것으로 나타났으며, Rf 의 경우 약 $0.32 \mathrm{mg} / \mathrm{g}$ 으로 큰 차이를 보이지 않았다. $\mathrm{Rg} 2$ 의 경우, 원료일 때 $2.34 \mathrm{mg} / \mathrm{g}$ 에서 15 분 볶았을 때 $3.13 \mathrm{mg} / \mathrm{g}$ 으 로 함량이 증가하였다. $\mathrm{Rd} 2$ 또한 원료일 때 $3.09 \mathrm{mg} / \mathrm{g}$ 에서 5 분일 때 $7.54 \mathrm{mg} / \mathrm{g}, 10$ 분일 때 $8.52 \mathrm{mg} / \mathrm{g}, 15$ 분 볶았을 때 $11.37 \mathrm{mg} / \mathrm{g}$ 으로 약 4배 증가하였다. F2 및 $\mathrm{Rg} 3$ 또한 원료일 때 각각 $5.23 \mathrm{mg} / \mathrm{g}$ 및 $0.85 \mathrm{mg} / \mathrm{g}$ 에서 15 분 볶았을 때 7.55 $\mathrm{mg} / \mathrm{g}$ 및 $1.42 \mathrm{mg} / \mathrm{g}$ 으로 함량이 증가하였다. Compound $\mathrm{K}$ 는 원료일 때 $0.63 \mathrm{mg} / \mathrm{g}$ 에서 5 분 볶았을 때 $0.81 \mathrm{mg} / \mathrm{g}, 10$ 분 볶 았을 때 $0.98 \mathrm{mg} / \mathrm{g}$ 에서 15 분 볶았을 때 $1.81 \mathrm{mg} / \mathrm{g}$ 으로 함량 이 증가하였다. 지하부의 ginsenoside $\mathrm{Rg} 1$ 은 볶음 시간이 증 가할수록 함량이 원료일 때 $2.31 \mathrm{mg} / \mathrm{g}$ 에서 15 분 볶았을 때 $1.92 \mathrm{mg} / \mathrm{g}$ 으로 감소하였다. Ginsenoside F3, F1 및 proto- panaxtriol 화합물은 검출되지 않았다. Ginsenoside Rb1 또한 원료일 때 $10.14 \mathrm{mg} / \mathrm{g}, 5$ 분 볶았을 때 $9.02 \mathrm{mg} / \mathrm{g}, 10$ 분 볶았 을 때 $8.57 \mathrm{mg} / \mathrm{g}$ 및 복음 시간이 15 분 볶았을 때 $7.07 \mathrm{mg} / \mathrm{g}$ 으로 함량이 감소하였다. Rc 또한 $4.85 \mathrm{mg} / \mathrm{g}$ 에서 $4.18 \mathrm{mg} / \mathrm{g}$, $3.91 \mathrm{mg} / \mathrm{g}, 15$ 분 볶았을 때 $3.26 \mathrm{mg} / \mathrm{g}$ 으로 감소하였다. $\mathrm{Rg} 3$ 및 compound $\mathrm{K}$ 의 경우 10 분 볶았을 때 $1.77 \mathrm{mg} / \mathrm{g}$ 및 1.24 $\mathrm{mg} / \mathrm{g}$ 으로 가장 높았으며, 15 분 볶았을 때 $0.96 \mathrm{mg} / \mathrm{g}$ 및 0.92 $\mathrm{mg} / \mathrm{g}$ 으로 두 번째로 높은 함량을 보였다.

Park 등(1996)은 인삼 박의 볶음 처리에 따른 ginsenosides 함량을 비교하였으며, 이중 ginsenosides Rb1와 Re, Rg1의 함 량이 감소하는 것으로 보고하였다. 또한 이는 진세노사이드 의 C-20 위치에 결합되어 있는 당이 열이나 산에 의해 쉽게 분해되기 때문이라고 보고하였다. 본 연구에서도 $\mathrm{Rb} 1$ 와 $\mathrm{Re}$ 등은 볶음 시간이 증가함에 따라 함량이 감소하였으며, 당이 
Table 5. Comprehensive changes of ginsenoside contents of ginseng sprouts (above and below ground) according to the roasting process

\begin{tabular}{|c|c|c|c|c|c|c|c|c|}
\hline \multirow{2}{*}{ Contents (mg/100 g) } & \multicolumn{4}{|c|}{ Above ground / Roasting time $\left(\mathrm{min}, 150^{\circ} \mathrm{C}\right)$} & \multicolumn{4}{|c|}{ Below ground / Roasting time $\left(\mathrm{min}, 200^{\circ} \mathrm{C}\right)$} \\
\hline & 0 & 5 & 10 & 15 & 0 & 5 & 10 & 15 \\
\hline \multicolumn{9}{|l|}{ Protopanaxtriol types } \\
\hline Ginsenoside Rg1 & $\begin{array}{c}5.90 \\
\pm 0.30^{\text {al) }}\end{array}$ & $\begin{array}{c} \\
4.42 \\
\pm 0.22^{\mathrm{ab}}\end{array}$ & $\begin{array}{c}4.05 \\
\pm 0.20^{\mathrm{b}}\end{array}$ & $\begin{array}{c}4.06 \\
\pm 0.20^{\mathrm{b}}\end{array}$ & $\begin{array}{c}2.31 \\
\pm 0.12^{\mathrm{c}}\end{array}$ & $\begin{array}{c}2.23 \\
\pm 0.11^{\mathrm{c}}\end{array}$ & $\begin{array}{c}2.31 \\
\pm 0.12^{\mathrm{c}}\end{array}$ & $\begin{array}{c}1.92 \\
\pm 0.10^{\mathrm{c}}\end{array}$ \\
\hline Ginsenoside Re & $\begin{array}{l}32.67 \\
\pm 1.63^{\mathrm{a}}\end{array}$ & $\begin{array}{l}21.02 \\
\pm 1.05^{\mathrm{b}}\end{array}$ & $\begin{array}{l}19.97 \\
\pm 1.00^{\mathrm{b}}\end{array}$ & $\begin{array}{c}19.40 \\
\pm 0.97^{b}\end{array}$ & $\begin{array}{c}5.40 \\
\pm 0.27^{\mathrm{c}}\end{array}$ & $\begin{array}{c}4.56 \\
\pm 0.23^{\mathrm{d}}\end{array}$ & $\begin{array}{c}5.13 \\
\pm 0.26^{\mathrm{cd}}\end{array}$ & $\begin{array}{c}4.42 \\
\pm 0.22^{\mathrm{d}}\end{array}$ \\
\hline Ginsenoside Rf & $\begin{array}{c}0.34 \\
\pm 0.02^{\mathrm{c}}\end{array}$ & $\begin{array}{c}0.34 \\
\pm 0.02^{\mathrm{c}}\end{array}$ & $\begin{array}{c}0.30 \\
\pm 0.02^{\mathrm{c}}\end{array}$ & $\begin{array}{c}0.31 \\
\pm 0.02^{\mathrm{c}}\end{array}$ & $\begin{array}{c}0.96 \\
\pm 0.05^{\mathrm{a}}\end{array}$ & $\begin{array}{c}0.89 \\
\pm 0.04^{\mathrm{a}}\end{array}$ & $\begin{array}{c}0.96 \\
\pm 0.05^{\mathrm{a}}\end{array}$ & $\begin{array}{c}0.79 \\
\pm 0.04^{\mathrm{b}}\end{array}$ \\
\hline Ginsenoside F5 & $\begin{array}{c}1.29 \\
\pm 0.06^{\mathrm{a}}\end{array}$ & $\begin{array}{l}0.87 \\
\pm 0.04^{\mathrm{b}}\end{array}$ & $\begin{array}{c}0.84 \\
\pm 0.04^{\mathrm{b}}\end{array}$ & $\begin{array}{c}0.97 \\
\pm 0.05^{\mathrm{a}}\end{array}$ & $\begin{array}{c}0.24 \\
\pm 0.01^{\mathrm{c}}\end{array}$ & $\begin{array}{c}0.22 \\
\pm 0.01^{\mathrm{c}}\end{array}$ & $\begin{array}{c}0.22 \\
\pm 0.01^{\mathrm{c}}\end{array}$ & $\begin{array}{c}0.21 \\
\pm 0.01^{\mathrm{c}}\end{array}$ \\
\hline Ginsenoside $\mathrm{F} 3$ & $\begin{array}{c}4.86 \\
\pm 0.24^{\mathrm{a}}\end{array}$ & $\begin{array}{c}3.27 \\
\pm 0.16^{\mathrm{b}}\end{array}$ & $\begin{array}{c}3.30 \\
\pm 0.17^{\mathrm{b}}\end{array}$ & $\begin{array}{c}3.68 \\
\pm 0.18^{\mathrm{ab}}\end{array}$ & $\mathrm{ND}^{2)}$ & ND & ND & ND \\
\hline Ginsenoside $\operatorname{Rg} 2$ & $\begin{array}{c}2.34 \\
\pm 0.12^{\mathrm{b}}\end{array}$ & $\begin{array}{c}2.35 \\
\pm 0.12^{\mathrm{b}}\end{array}$ & $\begin{array}{c}2.63 \\
\pm 0.13^{\mathrm{ab}}\end{array}$ & $\begin{array}{c}3.13 \\
\pm 0.16^{\mathrm{a}}\end{array}$ & $\begin{array}{c}0.64 \\
\pm 0.03^{\mathrm{c}}\end{array}$ & $\begin{array}{c}0.58 \\
\pm 0.03^{\mathrm{c}}\end{array}$ & $\begin{array}{c}0.61 \\
\pm 0.03^{\mathrm{c}}\end{array}$ & $\begin{array}{c}0.47 \\
\pm 0.02^{\mathrm{d}}\end{array}$ \\
\hline Ginsenoside Rh1 & $\begin{array}{c}0.45 \\
\pm 0.02^{\mathrm{d}}\end{array}$ & $\begin{array}{c}0.54 \\
\pm 0.03^{\mathrm{c}}\end{array}$ & $\begin{array}{c}0.62 \\
\pm 0.03^{\mathrm{b}}\end{array}$ & $\begin{array}{c}0.62 \\
\pm 0.03^{\mathrm{b}}\end{array}$ & $\begin{array}{c}0.76 \\
\pm 0.04^{\mathrm{a}}\end{array}$ & $\begin{array}{c}0.74 \\
\pm 0.04^{\mathrm{a}}\end{array}$ & $\begin{array}{c}0.71 \\
\pm 0.04^{\mathrm{a}}\end{array}$ & $\begin{array}{c}0.62 \\
\pm 0.03^{\mathrm{b}}\end{array}$ \\
\hline Ginsenoside F1 & $\begin{array}{c}1.68 \\
\pm 0.08^{\mathrm{a}}\end{array}$ & $\begin{array}{c}1.32 \\
\pm 0.07^{\mathrm{b}}\end{array}$ & $\begin{array}{c}1.31 \\
\pm 0.07^{\mathrm{b}}\end{array}$ & $\begin{array}{c}1.34 \\
\pm 0.07^{\mathrm{b}}\end{array}$ & ND & ND & ND & ND \\
\hline Protopanaxtriol & $\begin{array}{c}0.39 \\
\pm 0.02^{\mathrm{c}}\end{array}$ & $\begin{array}{c}0.96 \\
\pm 0.05^{\mathrm{b}}\end{array}$ & $\begin{array}{c}1.06 \\
\pm 0.05^{\mathrm{b}}\end{array}$ & $\begin{array}{c}1.35 \\
\pm 0.07^{\mathrm{a}}\end{array}$ & ND & ND & ND & ND \\
\hline Total & 49.92 & 35.09 & 34.08 & 34.86 & 12.31 & 9.22 & 9.94 & 8.43 \\
\hline \multicolumn{9}{|l|}{ Protopanaxdiol types } \\
\hline Ginsenoside Rb1 & $\begin{array}{c}3.63 \\
\pm 0.18^{\mathrm{d}}\end{array}$ & $\begin{array}{c}2.74 \\
\pm 0.14^{\mathrm{e}}\end{array}$ & $\begin{array}{c}2.49 \\
\pm 0.12^{\mathrm{e}}\end{array}$ & $\begin{array}{c}2.48 \\
\pm 0.12^{\mathrm{e}}\end{array}$ & $\begin{array}{c}10.14 \\
\pm 0.51^{\mathrm{a}}\end{array}$ & $\begin{array}{c}9.02 \\
\pm 0.45^{\mathrm{ab}}\end{array}$ & $\begin{array}{c}8.57 \\
\pm 0.43^{\mathrm{b}}\end{array}$ & $\begin{array}{c}7.07 \\
\pm 0.35^{\mathrm{c}}\end{array}$ \\
\hline Ginsenoside Rc & $\begin{array}{c}3.37 \\
\pm 0.17^{\mathfrak{c}}\end{array}$ & $\begin{array}{l}2.27 \\
\pm 0.1^{\mathrm{d}}\end{array}$ & $\begin{array}{c}2.21 \\
\pm 0.11^{\mathrm{d}}\end{array}$ & $\begin{array}{c}2.23 \\
\pm 0.11^{\mathrm{d}}\end{array}$ & $\begin{array}{c}4.85 \\
\pm 0.24^{\mathrm{a}}\end{array}$ & $\begin{array}{c}4.18 \\
\pm 0.21^{\mathrm{ab}}\end{array}$ & $\begin{array}{c}3.91 \\
\pm 0.20^{\mathrm{b}}\end{array}$ & $\begin{array}{c}3.26 \\
\pm 0.16^{\mathrm{c}}\end{array}$ \\
\hline Ginsenoside Rb2 & $\begin{array}{c}5.68 \\
\pm 0.28^{\mathrm{a}}\end{array}$ & $\begin{array}{c}3.74 \\
\pm 0.19^{\mathrm{b}}\end{array}$ & $\begin{array}{c}3.70 \\
\pm 0.19^{\mathrm{b}}\end{array}$ & $\begin{array}{c}3.70 \\
\pm 0.19^{\mathrm{b}}\end{array}$ & $\begin{array}{c}3.08 \\
\pm 0.15^{\mathrm{bc}}\end{array}$ & $\begin{array}{c}2.53 \\
\pm 0.13^{\mathrm{c}}\end{array}$ & $\begin{array}{c}2.42 \\
\pm 0.12^{\mathrm{c}}\end{array}$ & $\begin{array}{c}2.12 \\
\pm 0.11^{\mathrm{c}}\end{array}$ \\
\hline Ginsenoside Rb3 & $\begin{array}{c}0.72 \\
\pm 0.04^{\mathrm{a}}\end{array}$ & $\begin{array}{c}0.45 \\
\pm 0.02^{\mathrm{b}}\end{array}$ & $\begin{array}{c}0.44 \\
\pm 0.02^{\mathrm{b}}\end{array}$ & $\begin{array}{c}0.43 \\
\pm 0.02^{\mathrm{b}}\end{array}$ & $\begin{array}{c}0.48 \\
\pm 0.02^{\mathrm{b}}\end{array}$ & $\begin{array}{l}0.27 \\
\pm 0.01^{\mathrm{d}}\end{array}$ & $\begin{array}{c}0.42 \\
\pm 0.02^{\mathrm{b}}\end{array}$ & $\begin{array}{c}0.38 \\
\pm 0.02^{\mathrm{c}}\end{array}$ \\
\hline Ginsenoside $\mathrm{Rd}$ & $\begin{array}{l}20.57 \\
\pm 1.03^{\mathrm{a}}\end{array}$ & $\begin{array}{l}15.72 \\
\pm 0.79^{c}\end{array}$ & $\begin{array}{c}16.33 \\
\pm 0.82^{\mathrm{bc}}\end{array}$ & $\begin{array}{c}17.87 \\
\pm 0.89^{\mathrm{b}}\end{array}$ & $\begin{array}{c}1.98 \\
\pm 0.09^{\mathrm{d}}\end{array}$ & $\begin{array}{c}1.62 \\
\pm 0.08^{\mathrm{e}}\end{array}$ & $\begin{array}{c}2.13 \\
\pm 0.11^{\mathrm{d}}\end{array}$ & $\begin{array}{l}1.41 \\
\pm 0.07^{\mathrm{f}}\end{array}$ \\
\hline Ginsenoside $\mathrm{Rd} 2$ & $\begin{array}{c}3.09 \\
\pm 0.15^{\mathrm{d}}\end{array}$ & $\begin{array}{c}7.54 \\
\pm 0.38^{\mathrm{c}}\end{array}$ & $\begin{array}{c}8.52 \\
\pm 0.43^{\mathrm{b}}\end{array}$ & $\begin{array}{l}11.37 \\
\pm 0.57^{\mathrm{a}}\end{array}$ & $\begin{array}{c}1.59 \\
\pm 0.08^{\mathrm{f}}\end{array}$ & $\begin{array}{c}1.42 \\
\pm 0.07^{\mathrm{g}}\end{array}$ & $\begin{array}{c}1.75 \\
\pm 0.09^{\mathrm{e}}\end{array}$ & $\begin{array}{c}1.46 \\
\pm 0.07^{\mathrm{g}}\end{array}$ \\
\hline Ginsenoside F2 & $\begin{array}{c}5.23 \\
\pm 0.26^{\mathrm{c}}\end{array}$ & $\begin{array}{c}5.46 \\
\pm 0.27^{\mathrm{c}}\end{array}$ & $\begin{array}{c}6.80 \\
\pm 0.34^{\mathrm{b}}\end{array}$ & $\begin{array}{c}7.55 \\
\pm 0.38^{\mathrm{a}}\end{array}$ & $\begin{array}{c}0.49 \\
\pm 0.02^{\mathrm{g}}\end{array}$ & $\begin{array}{c}0.59 \\
\pm 0.03^{\mathrm{f}}\end{array}$ & $\begin{array}{c}0.90 \\
\pm 0.05^{\mathrm{d}}\end{array}$ & $\begin{array}{c}0.74 \\
\pm 0.04^{\mathrm{e}}\end{array}$ \\
\hline Ginsenoside Rg3 & $\begin{array}{c}0.85 \\
\pm 0.04^{\mathrm{c}}\end{array}$ & $\begin{array}{c}0.91 \\
\pm 0.05^{\mathrm{c}}\end{array}$ & $\begin{array}{c}0.98 \\
\pm 0.05^{\mathrm{c}}\end{array}$ & $\begin{array}{c}1.42 \\
\pm 0.07^{\mathrm{b}}\end{array}$ & $\begin{array}{c}0.42 \\
\pm 0.02^{\mathrm{e}}\end{array}$ & $\begin{array}{c}0.61 \\
\pm 0.03^{\mathrm{d}}\end{array}$ & $\begin{array}{c}1.77 \\
\pm 0.09^{\mathrm{a}}\end{array}$ & $\begin{array}{c}0.96 \\
\pm 0.05^{\mathrm{c}}\end{array}$ \\
\hline Compound $\mathrm{K}$ & $\begin{array}{c}0.63 \\
\pm 0.03^{\mathrm{f}}\end{array}$ & $\begin{array}{c}0.81 \\
\pm 0.04^{\mathrm{d}}\end{array}$ & $\begin{array}{c}0.98 \\
\pm 0.05^{\mathrm{c}}\end{array}$ & $\begin{array}{c}1.81 \\
\pm 0.09^{\mathrm{a}}\end{array}$ & $\begin{array}{c}0.47 \\
\pm 0.02^{\mathrm{g}}\end{array}$ & $\begin{array}{c}0.76 \\
\pm 0.04^{\mathrm{e}}\end{array}$ & $\begin{array}{c}1.24 \\
\pm 0.06^{\mathrm{b}}\end{array}$ & $\begin{array}{c}0.92 \\
\pm 0.05^{\mathrm{c}}\end{array}$ \\
\hline Ginsenoside Rh2 & $\begin{array}{c}0.65 \\
\pm 0.03^{\mathrm{b}}\end{array}$ & $\begin{array}{c}0.66 \\
\pm 0.03^{\mathrm{b}}\end{array}$ & $\begin{array}{c}0.66 \\
\pm 0.03^{\mathrm{b}}\end{array}$ & $\begin{array}{c}0.94 \\
\pm 0.05^{\mathrm{a}}\end{array}$ & $\begin{array}{c}0.12 \\
\pm 0.01^{\mathrm{f}}\end{array}$ & $\begin{array}{c}0.24 \\
\pm 0.01^{\mathrm{e}}\end{array}$ & $\begin{array}{c}0.40 \\
\pm 0.02^{\mathrm{c}}\end{array}$ & $\begin{array}{c}0.33 \\
\pm 0.02^{\mathrm{d}}\end{array}$ \\
\hline Protopanaxdiol & $\begin{array}{c}0.50 \\
\pm 0.03^{\mathrm{b}}\end{array}$ & $\begin{array}{c}0.23 \\
\pm 0.01^{\mathrm{d}}\end{array}$ & $\begin{array}{c}0.30 \\
\pm 0.02^{\mathrm{c}}\end{array}$ & $\begin{array}{c}0.77 \\
\pm 0.04^{\mathrm{a}}\end{array}$ & ND & ND & ND & ND \\
\hline
\end{tabular}


(continued)

\begin{tabular}{|c|c|c|c|c|c|c|c|c|}
\hline \multirow{2}{*}{ Contents (mg/100 g) } & \multicolumn{4}{|c|}{ Above ground / Roasting time $\left(\min , 150^{\circ} \mathrm{C}\right)$} & \multicolumn{4}{|c|}{ Below ground / Roasting time $\left(\min , 200^{\circ} \mathrm{C}\right)$} \\
\hline & 0 & 5 & 10 & 15 & 0 & 5 & 10 & 15 \\
\hline Total & 44.92 & 40.53 & 43.41 & 50.57 & 23.62 & 21.24 & 23.51 & 18.65 \\
\hline \multicolumn{9}{|l|}{ Oleanane types } \\
\hline Ginsenoside Ro & $\begin{array}{c}6.89 \\
\pm 0.34^{\text {al) }}\end{array}$ & $\begin{array}{c}3.78 \\
\pm 0.19^{b}\end{array}$ & $\begin{array}{c}3.50 \\
\pm 0.18^{\mathrm{b}}\end{array}$ & $\begin{array}{c}3.85 \\
\pm 0.19^{b}\end{array}$ & $\begin{array}{c}1.46 \\
\pm 0.07^{\mathrm{e}}\end{array}$ & $\begin{array}{l}1.79 \\
\pm 0.09^{\mathrm{d}}\end{array}$ & $\begin{array}{c}2.59 \\
\pm 0.13^{\mathrm{c}}\end{array}$ & $\begin{array}{c}2.31 \\
\pm 0.12^{\mathrm{c}}\end{array}$ \\
\hline Total & 6.89 & 3.78 & 3.50 & 3.85 & 1.46 & 1.79 & 2.59 & 2.31 \\
\hline Total ginsenosides & 101.73 & 79.40 & 80.99 & 89.28 & 37.39 & 32.25 & 36.04 & 29.39 \\
\hline
\end{tabular}

${ }^{1)}$ All values are presented as the mean $\pm \mathrm{SD}$ of triplicate determination. All values within a column with different superscript letters represent statistically significant difference from each other at $\mathrm{p}<0.05$ by Duncan's multiple range test.

${ }^{2)} \mathrm{ND}$, not detected

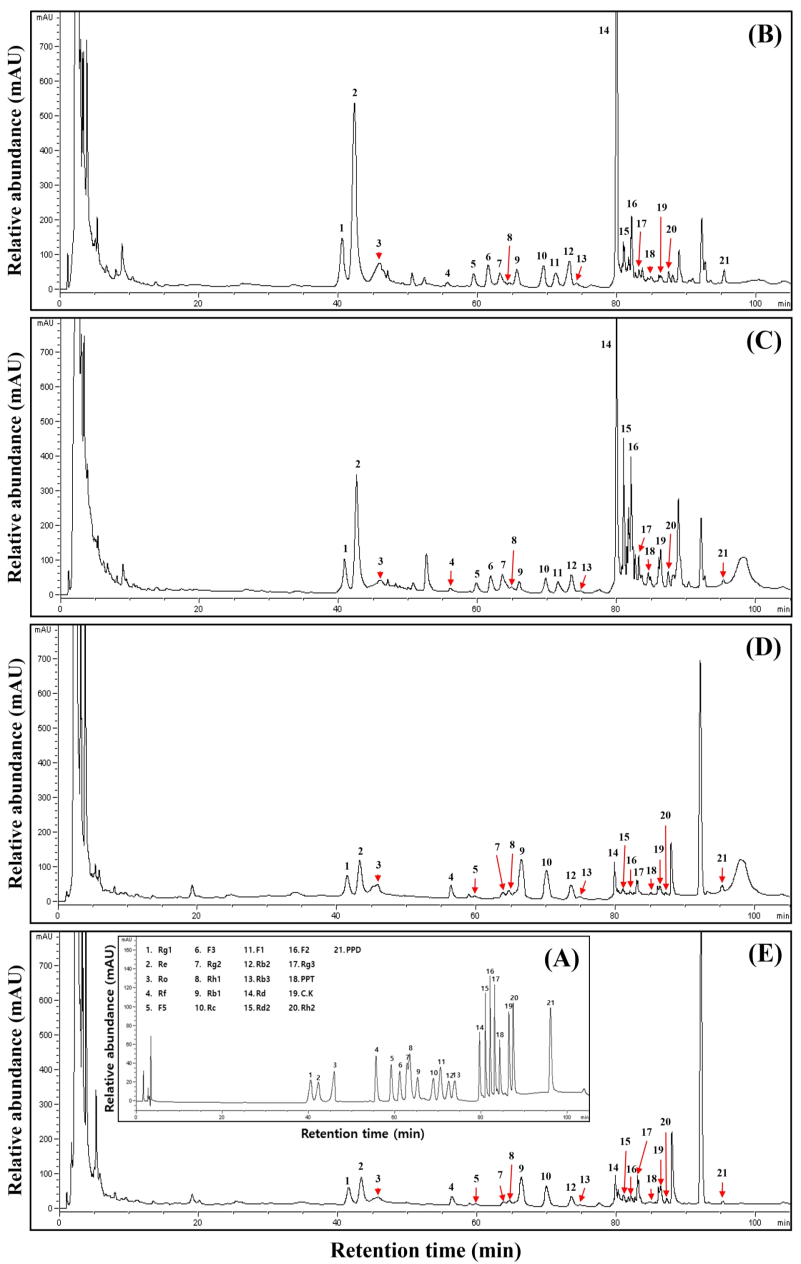

Fig. 3. The typical HPLC chromatogram of ginseng sprouts (above and below ground) according to the roasting process.

A, 21 ginsenoside standards; B, above ground for $0 \mathrm{~min}$ at $150^{\circ} \mathrm{C}$; C, above ground for $10 \mathrm{~min}$ at $150^{\circ} \mathrm{C}$; D, below ground for $0 \mathrm{~min}$ at $200^{\circ} \mathrm{C}$; $\mathrm{E}$, below ground for $10 \mathrm{~min}$ at $200^{\circ} \mathrm{C}$.
떨어지면서 기존 화합물의 구조에서 당이 하나씩 떨어진 다 른 화합물로 전화되었을 것으로 판단된다.

\section{볶음 처리에 따른 새싹인삼의 phenolic acids 및 flavonols 함량 변화}

새싹인삼의 볶음 처리에 따른 지상부 및 지하부의 phenolic acids 및 flavonols 함량은 Table 6과 같았다. 지상부의 gallic acid 함량은 원료일 때 $12.26 \mathrm{mg} / 100 \mathrm{~g}$ 에서 15 분 볶았을 때 $33.58 \mathrm{mg} / 100 \mathrm{~g}$ 으로 볶음 시간이 증가할수록 함량이 증가하 였다. Chlorogenic acid 및 ferulic acid의 함량 역시 볶음 시 간이 증가할수록 함량이 증가하였다. 이에 총 phenolic acid 함량 역시 원료일 때 $205.74 \mathrm{mg} / 100 \mathrm{~g}$ 에서 5 분(265.34 $\mathrm{mg} / 100 \mathrm{~g}), 10$ 분 $(345.11 \mathrm{mg} / 100 \mathrm{~g}), 15$ 분 볶음 처리하였을 때 $388.34 \mathrm{mg} / 100 \mathrm{~g}$ 으로 증가하였다. Flavonols 화합물 중 epigallocatechin의 함량이 높게 나타났으며, 원료일 때 110.17 $\mathrm{mg} / 100 \mathrm{~g}, 5$ 분일 때 $204.00 \mathrm{mg} / 100 \mathrm{~g}, 10$ 분일 때 397.13 $\mathrm{mg} / 100 \mathrm{~g}, 15$ 분일 때 $408.14 \mathrm{mg} / 100 \mathrm{~g}$ 으로 함량이 증가하였 다. Quercetin 화합물은 15 분 볶음 처리하였을 때 307.98 $\mathrm{mg} / 100 \mathrm{~g}$ 으로 볶음 처리 시간이 증가할수록 함량이 증가하 였고, 총 flavonols 함량도 15 분 볶음 처리 시 $813.01 \mathrm{mg} / 100$ $\mathrm{g}$ 으로 가장 높았다. 지하부의 경우 protocatechuic acid의 함 량이 볶음 시간이 증가함에 따라 각각 $2.28 \mathrm{mg} / 100 \mathrm{~g}, 4.00$ $\mathrm{mg} / 100 \mathrm{~g}, 5.62 \mathrm{mg} / 100 \mathrm{~g}$ 및 $6.39 \mathrm{mg} / 100 \mathrm{~g}$ 으로 함량 또한 증가하는 것을 보였다. Ferulic acid의 함량은 원료일 때 5.09 $\mathrm{mg} / 100 \mathrm{~g}$ 에서 15 분 볶았을 때 $9.82 \mathrm{mg} / 100 \mathrm{~g}$ 으로 증가하였 다. 반면, t-cinnamic acid의 경우 볶음 시간이 증가할수록 원 료일 때 $3.42 \mathrm{mg} / 100 \mathrm{~g}$ 에서 15 분 볶았을 때 $0.41 \mathrm{mg} / 100 \mathrm{~g}$ 으 로 함량이 감소하였다. 그러나, 총 phenoilc acids 함량은 원 료에서 $133.01 \mathrm{mg} / 100 \mathrm{~g}, 5$ 분 볶았을 때 $144.02 \mathrm{mg} / 100 \mathrm{~g}$, 10 분 볶았을 때 $196.92 \mathrm{mg} / 100 \mathrm{~g}$ 및 15분 볶았을 때 206.97 
Table 6. Comprehensive changes of phenolic acid and flavonol contents of ginseng sprouts (above and below ground) according to the roasting process

\begin{tabular}{|c|c|c|c|c|c|c|c|c|}
\hline \multirow{2}{*}{ Contents $(\mathrm{mg} / 100 \mathrm{~g})$} & \multicolumn{4}{|c|}{ Above ground / Roasting time $\left(\min , 150^{\circ} \mathrm{C}\right)$} & \multicolumn{4}{|c|}{ Below ground / Roasting time $\left(\min , 200^{\circ} \mathrm{C}\right.$ ) } \\
\hline & 0 & 5 & 10 & 15 & 0 & 5 & 10 & 15 \\
\hline \multicolumn{9}{|l|}{ Phenolic acids } \\
\hline Gallic acid & $\begin{array}{c}12.26 \\
\pm 0.61^{\mathrm{e})}\end{array}$ & $\begin{array}{l}18.90 \\
\pm 0.95^{\mathrm{c}}\end{array}$ & $\begin{array}{l}32.27 \\
\pm 1.61^{\mathrm{a}}\end{array}$ & $\begin{array}{l}33.58 \\
\pm 1.68^{\mathrm{a}}\end{array}$ & $\begin{array}{c}5.80 \\
\pm 0.29^{\mathrm{f}}\end{array}$ & $\begin{array}{c}5.38 \\
\pm 0.27^{\mathrm{f}}\end{array}$ & $\begin{array}{l}15.73 \\
\pm 0.79^{\mathrm{d}}\end{array}$ & $\begin{array}{l}21.14 \\
\pm 1.06^{\mathrm{b}}\end{array}$ \\
\hline Protocatechuic acid & $\begin{array}{l}23.34 \\
\pm 1.17^{\mathrm{a}}\end{array}$ & $\begin{array}{l}25.77 \\
\pm 1.29^{\mathrm{a}}\end{array}$ & $\begin{array}{l}22.16 \\
\pm 1.11^{\mathrm{a}}\end{array}$ & $\begin{array}{l}24.43 \\
\pm 1.22^{\mathrm{a}}\end{array}$ & $\begin{array}{l}2.28 \\
\pm 0.11^{\mathrm{d}}\end{array}$ & $\begin{array}{c}4.00 \\
\pm 0.20^{\mathrm{c}}\end{array}$ & $\begin{array}{c}5.62 \\
\pm 0.28^{\mathrm{bc}}\end{array}$ & $\begin{array}{c}6.39 \\
\pm 0.32^{\mathrm{b}}\end{array}$ \\
\hline Chlorogenic acid & $\begin{array}{c}77.89 \\
\pm 3.89^{\text {cd }}\end{array}$ & $\begin{array}{l}87.07 \\
\pm 4.35^{\mathrm{c}}\end{array}$ & $\begin{array}{l}132.56 \\
\pm 6.63^{\mathrm{b}}\end{array}$ & $\begin{array}{l}148.17 \\
\pm 7.41^{\mathrm{a}}\end{array}$ & $\begin{array}{l}25.46 \\
\pm 1.27^{\mathrm{f}}\end{array}$ & $\begin{array}{l}42.79 \\
\pm 2.14^{\mathrm{e}}\end{array}$ & $\begin{array}{l}67.27 \\
\pm 3.36^{\mathrm{d}}\end{array}$ & $\begin{array}{l}58.87 \\
\pm 2.94^{\text {de }}\end{array}$ \\
\hline p-Hydrobenzoic acid & $\begin{array}{l}15.10 \\
\pm 0.76^{\mathrm{a}}\end{array}$ & $\begin{array}{l}12.46 \\
\pm 0.62^{\mathrm{b}}\end{array}$ & $\begin{array}{c}13.28 \\
\pm 0.66^{\mathrm{ab}}\end{array}$ & $\begin{array}{c}13.78 \\
\pm 0.69^{\mathrm{ab}}\end{array}$ & $\begin{array}{c}6.23 \\
\pm 0.31^{\mathrm{c}}\end{array}$ & $\begin{array}{c}4.38 \\
\pm 0.22^{\mathrm{e}}\end{array}$ & $\begin{array}{l}10.79 \\
\pm 0.54^{\mathrm{d}}\end{array}$ & $\begin{array}{c}5.75 \\
\pm 0.29^{c}\end{array}$ \\
\hline Vanillic acid & $\mathrm{ND}^{2)}$ & ND & ND & ND & ND & $\begin{array}{c}2.80 \\
\pm 0.14^{\mathrm{a}}\end{array}$ & ND & $\begin{array}{c}0.46 \\
\pm 0.02^{\mathrm{b}}\end{array}$ \\
\hline p-Coumaric acid & $\begin{array}{l}2.11 \\
\pm 0.11^{\mathrm{d}}\end{array}$ & $\begin{array}{c}4.56 \\
\pm 0.23^{\mathrm{c}}\end{array}$ & $\begin{array}{c}6.15 \\
\pm 0.31^{\mathrm{b}}\end{array}$ & $\begin{array}{c}7.54 \\
\pm 0.38^{\mathrm{a}}\end{array}$ & $\begin{array}{c}4.14 \\
\pm 0.21^{\mathrm{c}}\end{array}$ & $\begin{array}{l}2.62 \\
\pm 0.13^{\mathrm{d}}\end{array}$ & $\begin{array}{l}2.24 \\
\pm 0.11^{\mathrm{d}}\end{array}$ & $\begin{array}{l}2.61 \\
\pm 0.13^{\mathrm{d}}\end{array}$ \\
\hline Ferulic acid & $\begin{array}{c}4.08 \\
\pm 0.20^{\mathrm{e}}\end{array}$ & $\begin{array}{c}9.95 \\
\pm 0.50^{\mathrm{b}}\end{array}$ & $\begin{array}{l}12.85 \\
\pm 0.64^{\mathrm{a}}\end{array}$ & $\begin{array}{l}13.37 \\
\pm 0.67^{\mathrm{a}}\end{array}$ & $\begin{array}{c}5.09 \\
\pm 0.25^{\mathrm{de}}\end{array}$ & $\begin{array}{c}5.51 \\
\pm 0.28^{\mathrm{d}}\end{array}$ & $\begin{array}{c}6.74 \\
\pm 0.34^{\mathrm{c}}\end{array}$ & $\begin{array}{c}9.82 \\
\pm 0.49^{\mathrm{b}}\end{array}$ \\
\hline Veratric acid & $\begin{array}{c}1.22 \\
\pm 0.06^{\mathrm{c}}\end{array}$ & $\begin{array}{c}1.42 \\
\pm 0.07^{\mathrm{c}}\end{array}$ & $\begin{array}{c}1.58 \\
\pm 0.08^{\mathrm{c}}\end{array}$ & $\begin{array}{c}4.48 \\
\pm 0.22^{\mathrm{a}}\end{array}$ & $\begin{array}{c}3.88 \\
\pm 0.19^{\mathrm{ab}}\end{array}$ & $\begin{array}{c}3.70 \\
\pm 0.19^{\mathrm{ab}}\end{array}$ & $\begin{array}{c}3.42 \\
\pm 0.17^{\mathrm{b}}\end{array}$ & $\begin{array}{c}5.11 \\
\pm 0.26^{\mathrm{a}}\end{array}$ \\
\hline Benzoic acid & $\begin{array}{l}68.00 \\
\pm 3.40^{\mathrm{e}}\end{array}$ & $\begin{array}{l}104.87 \\
\pm 5.24^{\mathrm{c}}\end{array}$ & $\begin{array}{l}123.93 \\
\pm 6.20^{\mathrm{b}}\end{array}$ & $\begin{array}{l}142.53 \\
\pm 7.13^{\mathrm{a}}\end{array}$ & $\begin{array}{l}76.71 \\
\pm 3.84^{\text {de }}\end{array}$ & $\begin{array}{l}72.50 \\
\pm 3.63^{\mathrm{e}}\end{array}$ & $\begin{array}{l}84.70 \\
\pm 4.24^{\mathrm{d}}\end{array}$ & $\begin{array}{l}96.41 \\
\pm 4.82^{\mathrm{c}}\end{array}$ \\
\hline$t$-Cinnamic acid & $\begin{array}{c}1.74 \\
\pm 0.09^{\mathrm{b}}\end{array}$ & $\begin{array}{c}0.34 \\
\pm 0.02^{\mathrm{d}}\end{array}$ & $\begin{array}{c}0.33 \\
\pm 0.02^{\mathrm{d}}\end{array}$ & $\begin{array}{c}0.46 \\
\pm 0.02^{\mathrm{c}}\end{array}$ & $\begin{array}{c}3.42 \\
\pm 0.17^{\mathrm{a}}\end{array}$ & $\begin{array}{c}0.34 \\
\pm 0.02^{\mathrm{d}}\end{array}$ & $\begin{array}{c}0.41 \\
\pm 0.02^{\mathrm{c}}\end{array}$ & $\begin{array}{c}0.41 \\
\pm 0.02^{\mathrm{c}}\end{array}$ \\
\hline Total & 205.74 & 265.34 & 345.11 & 388.34 & 133.01 & 144.02 & 196.92 & 206.97 \\
\hline \multicolumn{9}{|l|}{ Flavonols } \\
\hline Epigallocatechin & $\begin{array}{l}110.17 \\
\pm 5.51^{\mathrm{f}}\end{array}$ & $\begin{array}{l}204.00 \\
\pm 10.20^{c}\end{array}$ & $\begin{array}{c}397.13 \\
\pm 19.86^{\mathrm{a}}\end{array}$ & $\begin{array}{l}408.14 \\
\pm 20.41^{\mathrm{a}}\end{array}$ & $\begin{array}{l}131.16 \\
\pm 6.56^{\mathrm{e}}\end{array}$ & $\begin{array}{l}161.95 \\
\pm 8.10^{\mathrm{d}}\end{array}$ & $\begin{array}{c}202.31 \\
\pm 10.12^{\mathrm{c}}\end{array}$ & $\begin{array}{r}300.74 \\
\pm 15.04^{b}\end{array}$ \\
\hline Catechin & $\begin{array}{l}16.07 \\
\pm 0.80^{\mathrm{c}}\end{array}$ & $\begin{array}{l}34.44 \\
\pm 1.72^{\mathrm{a}}\end{array}$ & $\begin{array}{l}32.75 \\
\pm 1.64^{\mathrm{a}}\end{array}$ & $\begin{array}{l}37.23 \\
\pm 1.86^{\mathrm{a}}\end{array}$ & $\begin{array}{l}19.58 \\
\pm 0.98^{\mathrm{b}}\end{array}$ & $\begin{array}{l}14.01 \\
\pm 0.70^{\mathrm{d}}\end{array}$ & $\begin{array}{l}14.83 \\
\pm 0.74^{\mathrm{d}}\end{array}$ & $\begin{array}{l}18.02 \\
\pm 0.90^{\mathrm{b}}\end{array}$ \\
\hline Epicatechin & $\begin{array}{l}15.67 \\
\pm 0.78^{\mathrm{b}}\end{array}$ & $\begin{array}{l}21.17 \\
\pm 1.06^{\mathrm{a}}\end{array}$ & $\begin{array}{l}13.87 \\
\pm 0.69^{\mathrm{c}}\end{array}$ & $\begin{array}{l}13.88 \\
\pm 0.69^{c}\end{array}$ & $\begin{array}{c}9.69 \\
\pm 0.48^{\mathrm{e}}\end{array}$ & $\begin{array}{c}7.45 \\
\pm 0.37^{\mathrm{g}}\end{array}$ & $\begin{array}{l}8.50 \\
\pm 0.43^{\mathrm{f}}\end{array}$ & $\begin{array}{l}11.21 \\
\pm 0.56^{\mathrm{d}}\end{array}$ \\
\hline Epigallocatechin gallate & $\begin{array}{l}13.22 \\
\pm 0.66^{\mathrm{e}}\end{array}$ & $\begin{array}{l}15.22 \\
\pm 0.76^{\mathrm{c}}\end{array}$ & $\begin{array}{l}10.98 \\
\pm 0.55^{\mathrm{f}}\end{array}$ & $\begin{array}{l}11.71 \\
\pm 0.59^{f}\end{array}$ & $\begin{array}{l}14.53 \\
\pm 0.73^{\mathrm{d}}\end{array}$ & $\begin{array}{l}15.69 \\
\pm 0.78^{\mathrm{c}}\end{array}$ & $\begin{array}{l}17.16 \\
\pm 0.86^{\mathrm{b}}\end{array}$ & $\begin{array}{l}20.31 \\
\pm 1.02^{\mathrm{a}}\end{array}$ \\
\hline Vanillin & ND & ND & ND & ND & ND & ND & ND & ND \\
\hline Rutin & $\begin{array}{c}5.47 \\
\pm 0.27^{\mathrm{c}}\end{array}$ & $\begin{array}{c}3.51 \\
\pm 0.18^{\mathrm{d}}\end{array}$ & $\begin{array}{l}21.50 \\
\pm 1.08^{\mathrm{a}}\end{array}$ & $\begin{array}{l}14.45 \\
\pm 0.72^{\mathrm{b}}\end{array}$ & $\begin{array}{c}0.80 \\
\pm 0.04^{\mathrm{f}}\end{array}$ & $\begin{array}{c}2.22 \\
\pm 0.11^{\mathrm{e}}\end{array}$ & $\begin{array}{c}4.74 \\
\pm 0.24^{\mathrm{c}}\end{array}$ & $\begin{array}{r}5.46 \\
\pm 0.27^{\mathrm{c}}\end{array}$ \\
\hline Catechin gallate & $\begin{array}{c}9.19 \\
\pm 0.46^{\text {cd }}\end{array}$ & $\begin{array}{l}10.86 \\
\pm 0.54^{\mathrm{b}}\end{array}$ & $\begin{array}{l}12.80 \\
\pm 0.64^{\mathrm{a}}\end{array}$ & $\begin{array}{c}9.63 \\
\pm 0.48^{\mathrm{c}}\end{array}$ & $\begin{array}{l}3.91 \\
\pm 0.20^{\mathrm{f}}\end{array}$ & $\begin{array}{c}5.52 \\
\pm 0.28^{\mathrm{e}}\end{array}$ & $\begin{array}{c}8.56 \\
\pm 0.43^{\mathrm{d}}\end{array}$ & $\begin{array}{l}8.66 \\
\pm 0.43^{\mathrm{d}}\end{array}$ \\
\hline Quercetin & $\begin{array}{l}123.11 \\
\pm 6.16^{\mathrm{e}}\end{array}$ & $\begin{array}{l}211.12 \\
\pm 10.56^{\mathrm{c}}\end{array}$ & $\begin{array}{c}270.28 \\
\pm 13.51^{b}\end{array}$ & $\begin{array}{c}307.98 \\
\pm 15.40^{\mathrm{a}}\end{array}$ & $\begin{array}{l}53.44 \\
\pm 2.67^{\mathrm{f}}\end{array}$ & $\begin{array}{l}180.52 \\
\pm 9.03^{\mathrm{d}}\end{array}$ & $\begin{array}{l}194.66 \\
\pm 9.73^{\mathrm{cd}}\end{array}$ & $\begin{array}{l}206.67 \\
\pm 10.33^{\mathrm{c}}\end{array}$ \\
\hline Naringin & $\begin{array}{c}2.22 \\
\pm 0.11^{\mathrm{e}}\end{array}$ & $\begin{array}{c}4.02 \\
\pm 0.20^{\mathrm{d}}\end{array}$ & $\begin{array}{c}8.99 \\
\pm 0.45^{\mathrm{a}}\end{array}$ & $\begin{array}{c}2.31 \\
\pm 0.12^{\mathrm{e}}\end{array}$ & $\begin{array}{c}3.85 \\
\pm 0.19^{\mathrm{d}}\end{array}$ & $\begin{array}{c}5.34 \\
\pm 0.27^{\mathrm{c}}\end{array}$ & $\begin{array}{c}7.29 \\
\pm 0.36^{\mathrm{b}}\end{array}$ & $\begin{array}{c}8.11 \\
\pm 0.41^{\mathrm{a}}\end{array}$ \\
\hline Naringenin & $\begin{array}{l}2.16 \\
\pm 0.11^{\mathrm{d}}\end{array}$ & $\begin{array}{c}2.69 \\
\pm 0.13^{\text {cd }}\end{array}$ & $\begin{array}{c}2.85 \\
\pm 0.14^{\mathrm{c}}\end{array}$ & $\begin{array}{c}4.18 \\
\pm 0.21^{\mathrm{ab}}\end{array}$ & $\begin{array}{l} \\
\quad 4.17 \\
\pm 0.21^{\mathrm{ab}}\end{array}$ & $\begin{array}{c}3.82 \\
\pm 0.19^{\mathrm{b}}\end{array}$ & $\begin{aligned} & 4.35 \\
\pm & 0.22^{\mathrm{a}}\end{aligned}$ & $\begin{array}{c}4.62 \\
\pm 0.23^{\mathrm{a}}\end{array}$ \\
\hline Formonoetin & $\begin{aligned} & 3.15 \\
\pm & 0.16^{\mathrm{bc}}\end{aligned}$ & $\begin{array}{c}2.85 \\
\pm 0.14^{\mathrm{c}}\end{array}$ & $\begin{aligned} & 3.17 \\
\pm & 0.16^{\mathrm{bc}}\end{aligned}$ & $\begin{array}{c}3.50 \\
\pm 0.18^{\mathrm{b}}\end{array}$ & $\begin{array}{l}2.46 \\
\pm 0.12^{\mathrm{d}}\end{array}$ & ND & $\begin{aligned} & 3.16 \\
\pm 0.16 & \text { bc }\end{aligned}$ & $\begin{array}{c}4.49 \\
\pm 0.22^{\mathrm{a}}\end{array}$ \\
\hline Total & 300.43 & 509.88 & 774.32 & 813.01 & 243.59 & 396.52 & 465.56 & 588.29 \\
\hline
\end{tabular}

${ }^{1)}$ All values are presented as the mean \pm SD of triplicate determination. All values within a column with different superscript letters represent statistically significant difference from each other at $\mathrm{p}<0.05$ by Duncan's multiple range test.

${ }^{2)} \mathrm{ND}$, not detected. 
$\mathrm{mg} / 100 \mathrm{~g}$ 으로 함량이 증가하였다. Flavonols 중 rutin의 함량 은 새싹인삼 원료일 때 $0.80 \mathrm{mg} / 100 \mathrm{~g}$ 에서 15 분 볶았을 때 $5.46 \mathrm{mg} / 100 \mathrm{~g}$ 으로 증가하였다. 또한, quercetin 함량은 53.44 $\mathrm{mg} / 100 \mathrm{~g}$ 에서 $206.67 \mathrm{mg} / 100 \mathrm{~g}$ 으로 15 분 볶았을 때 볶음 처리를 하지 않았을 때보다 약 4 배 높은 함량을 보였다.

Cho와 Joo(2012)는 원료에 비해 볶음 처리를 하였을 때 gallic acid와 chlorogenic acid 등의 함량이 증가한다고 하였 고, 이는 볶음처리에 의해 ester 결합된 polyphenol 성분이 유 리형 phenolics으로 변환되어 함량이 증가한 것으로 보고하 였다. 본 연구의 결과도 볶음 시간이 증가함에 따라 함량이 증가하였고, 이에 항산화 활성이 증가될 것으로 추정된다. Choi 등(2012)은 여주를 부위별로 볶음 처리하여 phenolics 화합물을 분석하였는데, 본 연구결과와 유사하게 gallic acid
와 chlorogenic acid, ferulic acid 등이 증가한다고 보고하였 다. 또한 이중 gallic acid 및 기타 phenolic acid는 항산화 및 항암에 효과가 있다고 보고하였다.

\section{볶음 처리에 따른 새싹인삼의 항산화능 변화}

새싹인삼의 볶음 처리에 따른 항산화 활성은 Fig. 4 와 같 았다. DPPH 라디칼 소거활성의 경우, 지상부 및 지하부 모두 볶음 시간이 증가할수록 활성이 증가하는 것으로 나타났다. 원료일 때 지상부 및 지하부 각각 $47.36 \%$ 및 $25.32 \%$ 의 활성 을 보였으며, 15 분 볶음 처리하였을 때 $80.05 \%$ 및 $43.89 \%$ 의 활성을 보였다(Fig. $4 \mathrm{~A}) . \mathrm{ABTS}$ 라디칼 소거활성 또한 각 볶 음 시간에 따라 지상부의 경우 원료일 때 $54.81 \%, 5$ 분 볶음 처리하였을 때 $67.72 \%, 10$ 분 볶았을 때 $74.63 \%$ 및 15 분 볶
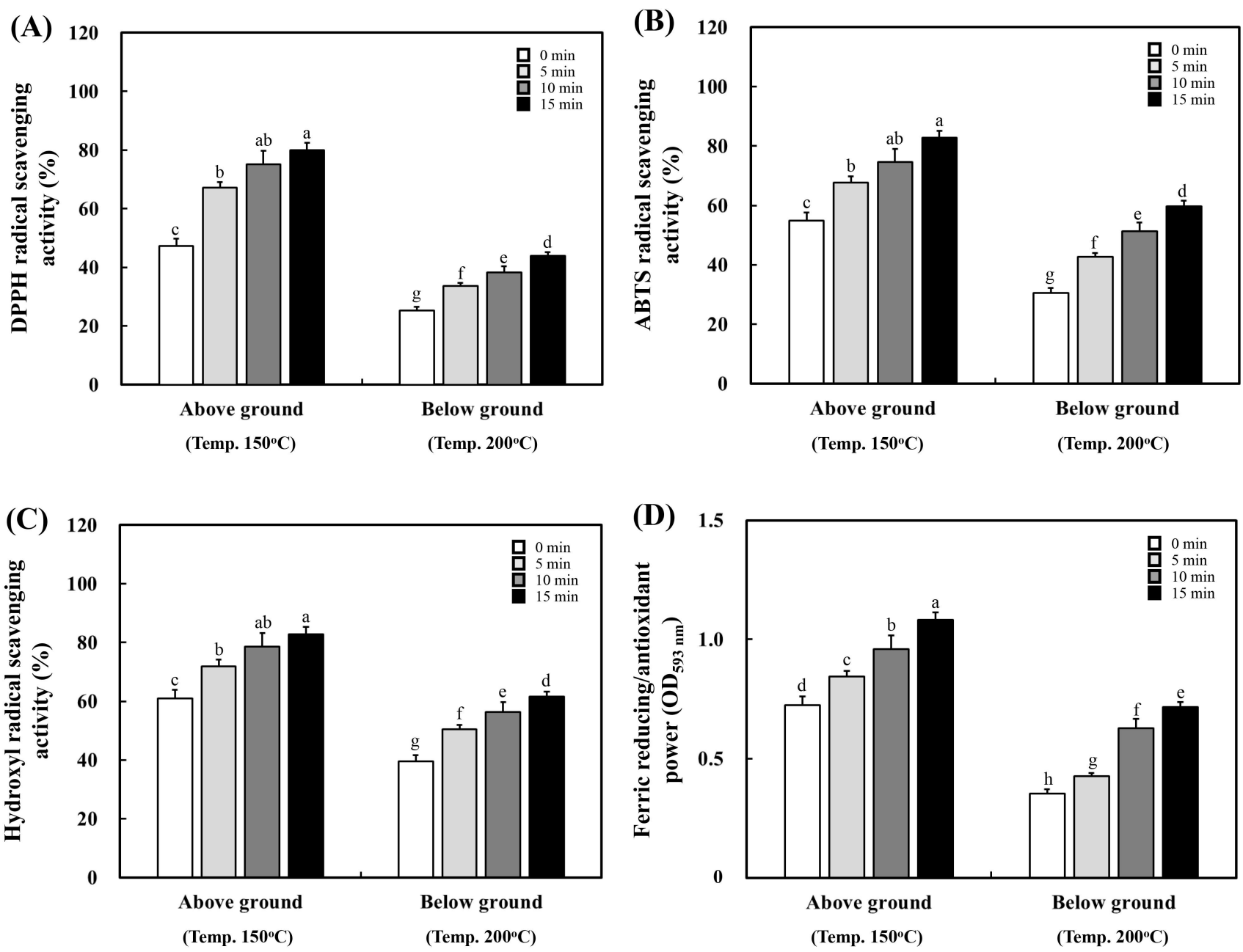

Fig. 4. Changes of antioxidant activities of ginseng sprouts (above and below ground) according to the roasting process.

A, DPPH radical scavenging activity; B, DPPH radical scavenging activity; C, hydroxyl radical scavenging activity; D, ferric reducing/antioxidant power.

All values are presented as the mean \pm SD of triplicate determination. All values within a column with different superscript letters represent statistically significant difference from each other at $\mathrm{p}<0.05$ by Duncan's multiple range test. 
음 처리하였을 때 $82.73 \%$ 의 활성을 보였고, 지하부 역시 각 각 $30.62 \%, 42.78 \%, 51.23 \%$ 및 $59.81 \%$ 로 15 분 볶았을 때 높은 활성을 보였다(Fig. 4B). Hydroxyl 라디칼 소거활성 또 한 앞선 두 라디칼 소거활성과 동일하게 지상부 및 지하부 각각 $82.81 \%$ 및 $61.51 \%$ 로 15 분 볶음 처리하였을 때 가장 높 은 활성을 보였다(Fig. $4 \mathrm{C}$ ). FRAP 환원력은 지상부에서 원 료일 때 $0.724 \mathrm{OD} 593 \mathrm{~nm}$ 로 나타났으며, 15 분 볶음 처리하였을 때 $1.082 \mathrm{OD} 593 \mathrm{~nm}$ 로 나타났다. 지하부 또한 볶음 처리하였을 때 $0.353 \mathrm{OD} 593 \mathrm{~nm}$ 에서 15 분 볶음 처리하였을 때 $0.715 \mathrm{OD} 593$ ${ }_{\mathrm{nm}}$ 로 증가하였다(Fig. 4D).

$\mathrm{Kim}$ 등(2018b)은 백하수오를 $120^{\circ} \mathrm{C}$ 와 $180^{\circ} \mathrm{C}$ 에서 원료 및 $1-4$ 분간 볶음 처리하여 DPPH 및 ABTS 라디칼 소거능을 비 교하였다. 원료일 때 $496.77 \mathrm{mg} / \mathrm{mL}$ 의 $\mathrm{IC}_{50}$ 값을 보였으나, 볶음처리 시간이 증가할수록 $\mathrm{DPPH}$ 활성이 높게 나타났다. 4 분간 볶음 처리하였을 때 $\mathrm{IC}_{50}$ 값이 온도별로 각각 264.05 $\mathrm{mg} / \mathrm{mL}$ 및 $107.25 \mathrm{mg} / \mathrm{mL}$ 로 나타났다. Kwon 등(2014)은 볶 음 처리에 따른 우엉차의 $\mathrm{ABTS}$ 라디칼 소거능을 비교하였 으며 볶음 처리로 인해 $75.13 \%$ 의 활성에서 $85.66 \%$ 로 활성 이 증가하였고 FRAP 환원력 역시 증가한다고 보고하였으며, 본 연구와 유사한 결과를 보고하였다. 총 phnolics 및 총 flavonoids의 함량이 볶음 처리하였을 때 증가하였으며, 이에 유사하게 항산화활성 또한 증가하는 것을 보였다. 이는 총 phenolics 및 총 flavonoids와 같은 polyphenol성 화합물이 항 산화 활성에 영향을 준다고 판단된다(Kwon 등, 2014).

\section{요 약}

본 연구에서는 볶음 처리한 새싹인삼의 이화학적 특성, 영 양성분 및 항산화 활성 변화를 비교하였다. 볶음 처리에 따라 새싹인삼의 지방산과 무기질의 함량은 거의 변화가 없었으나, 유리아미노산 함량은 감소하였다. 한편, 볶음 처리에 따라 ginsenosides 함량은 감소한 반면 총 phenolics, 총 flavonoids, 갈변물질, phenolic acids 및 flavonols은 증가하였다. 특히, 볶음 처리 중 진 ginsenoside $\operatorname{Re}$ (지상부: $32.67 \rightarrow 19.4$ 및 지하부: $5.4 \rightarrow 4.42 \mathrm{mg} / \mathrm{g}), \operatorname{Rbl}(3.63 \rightarrow 2.48$ 및 $10.14 \rightarrow$ $7.07 \mathrm{mg} / \mathrm{g})$ 과 $\operatorname{Rd}(20.57 \rightarrow 17.87$ 및 $1.98 \rightarrow 1.41 \mathrm{mg} / \mathrm{g})$ 함량 은 감소하였으나, $\operatorname{Rg} 3(0.85 \rightarrow 1.42$ 및 $0.42 \rightarrow 0.96 \mathrm{mg} / \mathrm{g})$, compound $\mathrm{K}(0.63 \rightarrow 1.81$ 및 $0.47 \rightarrow 0.92 \mathrm{mg} / \mathrm{g})$, chlorogenic $\operatorname{acid}(77.89 \rightarrow 148.17$ 및 $25.46 \rightarrow 58.87 \mu \mathrm{g} / \mathrm{g})$, epigallocatechin $(110.17 \rightarrow 408.14$ 및 $131.16 \rightarrow 300.74 \mu \mathrm{g} / \mathrm{g})$ 과 quercetin $(123.11 \rightarrow 307.98$ 및 $53.44 \rightarrow 206.67 \mu \mathrm{g} / \mathrm{g})$ 은 증가 하였다. 끝으로 $\mathrm{DPPH}, \mathrm{ABTS}$ 와 hydroxyl 라디칼 소거활성 과 FRAP 환원력의 항산화 활성은 새싹인삼의 볶음 처리 중 증가하였다.

\section{감사의 글}

본 연구는 2019년 국립경남과학기술대학교의 교원 연수 연구비 지원에 의하여 연구되었습니다.

\section{Conflict of interests}

The authors declare no potential conflict of interest.

\section{ORCID}

Su Cheol Kim https://orcid.org/0000-0002-8607-0151

Kye Man Cho https://orcid.org/0000-0002-5928-0532

\section{References}

Ahn MJ, Yuk HJ, Lee HY, Hwang CE, Jeong YS, Hong SY, Kwon OK, Kang SS, Kim HR, Park DS, Cho KM. Effect of the enhanced biological activities and reduced bitter taste of bitter melon (Momordica charantia L.) by roasting. J Agric Life Sci, 49, 107-119 (2015)

Cho KM, Hwang CE, Joo OS. Change of physicochemical properties, phytochemical contents and biological activities during the vinegar fermentation of Elaeagnus multiflora fruit. Korean J Food Preserv, 24, 125-133 (2017)

Cho KM, Joo OS. Enhances antioxidant effect of purple sweet potato by roasting. Korean J Food Preserv, 19, 735-743 (2012)

Choi JS, Kim HY, Seo WT, Lee JH, Cho KM. Roasting enhances antioxidant effect of bitter melon (Momordica charantia L.) increasing in flavan-3-ol and phenolic acid contents. Food Sci Biotechnol, 21, 19-26 (2012)

Folin O, Denis W. On phosphotungstic-phosphomolybdic compounds as color reagents. J Biol Chem, 12, 239-243 (1912)

Hong MJ, Lee GD, Kim HK, Kwon JH. Changes in functional and sensory properties of chicory roots induced by roasting processes. Korean J Food Sci Technol, 30, 413-418 (1998)

Hwang CE, An MJ, Lee HY, Lee BW, Kim HT, Ko JM, Baek IY, Seo WT, Cho KM. Potential probiotic Lactobacillus plantarum P1201 to produce soy-yogurt with enhanced antioxidant activity. Korean J Food Sci 
Technol, 46, 556-565 (2014)

Hwang CE, Lee DH, Joo OS, Lee HY, Kim SC, Park KS, Um BS, Cho KM. Comparison of physiochemical property, phytochemical contents, and biological activity of soy sauce added with bitter melon powder. Korean J Food Preserv, 24, 1138-1148 (2017)

Hwang CE, Seo WT, Cho KM. Enhanced antioxidant effect of black soybean by Cheonggukjang with potential probiotic Bacillus subtilis CSY191. Korean J Microbiol, 49, 391-397 (2013)

Jang HL, Park SY, Nam JS. The Effects of heat treatment on the nutritional composition and antioxidant properties of hempseed (Cannabis sativa L.). J Korean Soc Food Sci Nutr, 47, 885-894 (2018)

Jin HY, Moon HJ, Kim SH, Lee SC, Huh CK. Quality characteristics of blended tea with added pan-firing Rhus verniciflua seeds and changes in its antioxidant activity during storage. Korean J Food Sci Technol, 49, 318-323 (2017)

Jin Y, Kim YJ, Jeon JN, Wang C, Min JW, Jung SY, Yang DC. Changes of ginsenosides and physiochemical properties in ginseng by new 9 repetitive steaming and drying process. Korean J Plant Res, 25, 473-481 (2012)

Kang MJ, Shin SR, Kim KS. Antioxidative and free radical scavenging activity of water extract from dandelion (Taraxacum officinale). Korean J Food Preserv, 9, 253259 (2002)

Kim DS, Lee KB. Physiological characteristics and manufacturing of the processing products of sprouts vegetables. Korean J Food Cook Sci, 26, 238-245 (2010)

Kim DS, Kim HS, Hong SJ, Cho JJ, Shin EC. Changes in physicochemical and antioxidative properties of Cynanchi wilfordii Radix after a roasting treatment. J Korean Soc Food Sci Nutr, 47, 363-372 (2018b)

Kim GS, Hyun DY, Kim YO, Lee SE, Kwon H, Cha SW, Park CB, Kin YB. Investigation of ginsenosides in different parts of Panax ginseng cultured by hydroponics. Korean J Hortic Sci Technol, 28, 216-226 (2010) Kim SC, Im CY, Hwang CE, Park SW, Lee DH, Cho KM. Nutritional components, phytochemicals and biological activities of Sibjeondaebohwan produced from balloon flower by high-temperature aging. Korean J Food Preserv, 26, 483-495 (2019)

Kwon JH, Ryu KC, Lee GD. Dynamic changes in browning reaction substrates of Polygonatum odoratum roots during toasting. J Korean Soc Food Sci Nutr, 26, 654-661 (1997)

Kwon YR, Youn KS. Physicochemical of burdock (Arctium lappa L) tea depending on steaming and roasting treatment. Korean J Food Preserv, 21, 646-651 (2014)

Lee JH, Kim HJ, Kim MJ, Jung GH, Lee BW, Lee BK, Woo KS. Quality and antioxidant characteristics of roasted maize tea according to cultivation period and variety. J Korean Soc Food Sci Nutr, 46, 1316-1326 (2017)

Lee MH, Cho JH, Kim BK. Effect of roasting conditions on the antioxidant activities of Cassia tora L. Korean J Food Sci Technol, 45, 657-660 (2013)

Lee SE, Lee SW, Bang JK, Yu YJ, Seong NS. Antioxidant activities of leaf, stem and root of Panax ginseng C. A. Meyer. Korean J Medicinal Crop Sci, 12, 237-242 (2004)

Park MH, Kim KC, Kim JS. Changes in the physicochemical properties of ginseng by roasting. Korean $\mathrm{J}$ Ginseng Sci, 17, 228-231 (1993)

Park MH, Park CK, Lee KS, Kim KC. Changes of ginsenosides in ginseng marc by roasting process. Korean J Ginseng Sci, 20, 184-187 (1996)

Park SH, Sihn EH, Park SJ, Han JH. Ginsenoside contents and hypocholesterolemic effects of a by-product in ginseng radix. Korean J Ori Physiol Pathol, 19, 459-465 (2005)

Park SM, Jung EH, Kim JK, Jegal KH, Park CA, Cho IJ, Kim SC. 20S-Protopanaxadiol, and aglycosylated ginsenoside metabolite, induces hepatic stellate cell apoptosis through liver kinase B1-AMP-activated protein kinase activation. J Ginseng Res, 41, 392-402 (2017)

Seong BJ, Kim SI, Jee MG, Lee HC, Kwon AR, Kim HH, Won JY, Lee KS. Changes in growth, active ingredients, and rheological properties of greenhouse-cultivated ginseng sprout during its growth period. Korean J Medicinal Crop Sci, 27, 126-135 (2019)

Shin JH, Lee SJ, Seo JK, Cheon EW, Sung NJ. Antioxidant activity of hot-water extract from yuza (Citrus junos Seib ex Tanaka) peel. J Life Sci, 18, 1745-1751 (2008)

Van Boekel MAJS. Formation of flavour compounds in the maillard reaction. Biotechnol Adv, 24, 230-233 (2006) 